\title{
Self-reported functional health status following interrupted aortic arch repair: A Congenital Heart Surgeons' Society Study
}

Anusha Jegatheeswaran, MD, PhD, ${ }^{a}$ Marshall L. Jacobs, MD, ${ }^{\mathrm{b}}$ Christopher A. Caldarone, MD, ${ }^{\mathrm{a}}$ Paul M. Kirshbom, MD, ${ }^{\mathrm{c}}$ William G. Williams, MD, ${ }^{\mathrm{a}}$ Eugene H. Blackstone, $\mathrm{MD},{ }^{\mathrm{d}}$ William M. DeCampli, MD, PhD, ${ }^{e}$ Kim F. Duncan, MD, ${ }^{f}$ Linda M. Lambert, APRN, ${ }^{g}$ Henry L. Walters, MD, ${ }^{\mathrm{h}}$ Christo I. Tchervenkov, MD, ${ }^{\mathrm{i}}$ and Brian W. McCrindle, MD, MPH ${ }^{\mathrm{j}}$

\section{ABSTRACT}

Objectives: Improved survival after congenital heart surgery has led to interest in functional health status. We sought to identify factors associated with selfreported functional health status in adolescents and young adults with repaired interrupted aortic arch.

Methods: Follow-up of survivors (aged 13-24 years) from a 1987 to 1997 inception cohort of neonates included completion of functional health status questionnaires (Child Health Questionnaire-CF87 [age $<18$ years, $\mathrm{n}=51$ ] or the Short Form [SF]-36 [age $\geq 18$ years, $\mathrm{n}=66$ ]) and another about 22q11 deletion syndrome (22q11DS) features $(n=141)$. Factors associated with functional health status domains were determined using multivariable linear regression analysis.

Results: Domain scores of respondents were significantly greater than norms in 2 of 9 Child Health Questionnaire-CF87 and 4 of 10 SF-36 domains and only lower in the physical functioning domain of the SF-36. Factors most commonly associated with lower scores included those suggestive of 22q11DS (low calcium levels, recurrent childhood infections, genetic testing/diagnosis, abnormal facial features, hearing deficits), the presence of self-reported behavioral and mental health problems, and a greater number of procedures. Factors explained between $10 \%$ and $70 \%$ of domain score variability $\left(\mathrm{R}^{2}=0.10-0.70\right.$, adj- $\left.\mathrm{R}^{2}=0.09-0.66\right)$. Of note, morphology and repair type had a minor contribution.

Conclusions: Morbidities associated with 22q11DS, psychosocial issues, and recurrent medical issues affect functional health status more than initial morphology and repair in this population. Nonetheless, these patients largely perceive themselves as better than their peers. This demonstrates the chronic nature of interrupted aortic arch and suggests the need for strategies to decrease reinterventions and for evaluation of mental health and genetic issues to manage associated deteriorations. (J Thorac Cardiovasc Surg 2019;157:1577-87)
Interrupted Aortic Arch

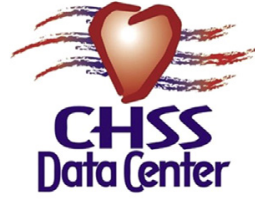

Functional Health Status in Adolescents \& Young Adults

Functional health status in adolescents and young adults with interrupted aortic arch.

\section{Central Message}

Morbidities associated with 22q11, psychosocial issues, and recurrent medical issues strongly affect functional health status in survivors of IAA; however, these survivors largely perceive themselves as better than their peers.

\section{Perspective}

We continue to demonstrate that IAA is a chronic disease and suggest the need for strategies to decrease reinterventions and to evaluate mental health and genetic issues. Longitudinal functional health status evaluation is also needed to ascertain changes related to increasing medical complexity, admissions and procedures, and those associated with mature adult roles and responsibilities.

See Commentaries on pages 1588 and pages 1590 .

\footnotetext{
From the ${ }^{\mathrm{a} D i v i s i o n}$ of Cardiac Surgery, Department of Surgery and ${ }^{\mathrm{j}}$ Division of Cardiology, Department of Pediatrics, University of Toronto, Hospital for Sick Children, Toronto, Ontario, Canada; ${ }^{\mathrm{b}}$ Division of Cardiac Surgery, Department of Surgery, Johns Hopkins University, Baltimore, Md; ${ }^{\mathrm{c}}$ Division of Cardiothoracic Surgery, Department of Surgery, Levine Children's Hospital, Charlotte, NC; ${ }^{\mathrm{d} D e-}$ partment of Thoracic and Cardiovascular Surgery, Lerner Research Institute, Cleveland Clinic Foundation, Cleveland, Ohio; ${ }^{\mathrm{e}}$ Division of Cardiac Surgery, Department of Surgery, University of Central Florida College of Medicine, Arnold Palmer Hospital for Children, Orlando, Fla; ${ }^{\mathrm{f}}$ Division of Cardiothoracic Surgery, Department of Surgery, University of Nebraska Medical Center, Omaha, Neb; ${ }^{\mathrm{g}} \mathrm{Di}$ vision of Cardiothoracic Surgery, Department of Surgery, University of Utah, Primary Children's Hospital, Salt Lake City, Utah; ${ }^{\mathrm{h}}$ Division of Cardiovascular Surgery, Department of Surgery, Wayne State University, Children's Hospital of
}

Michigan, Detroit, Mich; and ${ }^{\mathrm{i}}$ Division of Pediatric Cardiac Surgery, Department of Surgery, McGill University, Montreal Children's Hospital, Montreal, Quebec, Canada.

Funded by Congenital Heart Surgeons' Society institutional dues.

Received for publication March 13, 2018; revisions received Oct 15, 2018; accepted for publication Nov 11, 2018; available ahead of print Feb 13, 2019

Address for reprints: Anusha Jegatheeswaran, MD, PhD, FRCSC, Congenita Heart Surgeons' Society, Room 4433, Black Wing, Hospital for Sick Children, 555 University Ave, Toronto, Ontario M5G 1X8, Canada (E-mail: anusha jegatheeswaran@utoronto.ca). $0022-5223 / \$ 36.00$

Copyright (c) 2019 by The American Association for Thoracic Surgery https://doi.org/10.1016/j.jtcvs.2018.11.152 


$$
\begin{aligned}
& \text { Abbreviations and Acronyms } \\
& \text { 22q11DS }=22 \mathrm{q} 11 \text { deletion syndrome } \\
& \mathrm{CHD}=\text { congenital heart disease } \\
& \text { CHQ-CF87 = Child Health Questionnaire (CHQ) } \\
& \text { Version CF-87 } \\
& \text { CHSS = Congenital Heart Surgeons' Society } \\
& \text { FHS } \quad \text { functional health status } \\
& \text { IAA }=\text { interrupted aortic arch } \\
& \text { SF-36 = Short Form (36) Health Survey } \\
& \text { version } 2
\end{aligned}
$$

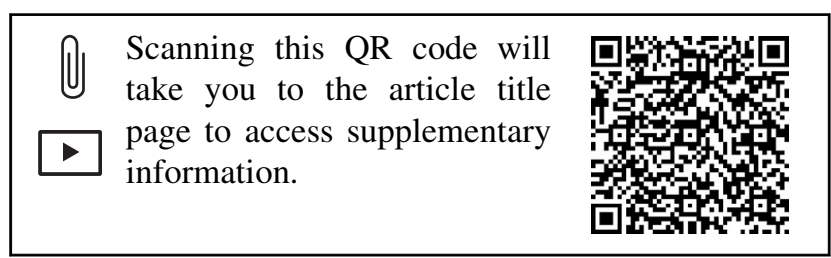

Outcomes in children with interrupted aortic arch (IAA) have been conventionally measured by using the metrics of survival and perioperative morbidity and mortality. As outcomes improve, survivors now have a greater expectation of longevity after repair, making morbidity and mortality measurements inadequate. Therefore, functional health status (FHS) has become an important outcome measure, as we assess how these patients fare as adolescents and adults, especially compared with those without disease.

FHS can be defined as the amount of disability a patient experiences secondary to his/her health care condition with regard to any domain in their life. It represents the ability of an individual to perform normal activities, such that they can fulfill basic needs, perform usual roles, and support both health and well-being. ${ }^{1,2}$ FHS instruments allow us to measure these domains of health and assess the impact of disease on a patient's life.

Previous studies of FHS in pediatric cardiac surgery survivors using questionnaires have displayed considerable variability, with domains scores showing lower, ${ }^{3-9}$ comparable, ${ }^{6,8-13}$ or even greater scores relative to population norms. ${ }^{6,8,9,14}$ However, many of these studies were based on parent-reported FHS, rather than selfreported FHS. Recent literature has focused on the perceptions of the patient (self-reports) as opposed to proxies, or has compared patient and proxy results. ${ }^{4,6-8,10,11,13}$ Using 2 of these nondisease-specific FHS questionnaires, the Child Health Questionnaire (CHQ) Version CF-87 (CHQCF87) and the Short Form (36) Health Survey version 2 (SF-36), the Congenital Heart Surgeons' Society (CHSS) sought to assess the late self-reported FHS of patients after
IAA repair and the patient-specific factors associated with scores in each domain. ${ }^{15}$

The goals of the analysis were to: (1) compare the FHS of patients with IAA with normative data, (2) determine whether adolescent or adult IAA populations have more deviation from normative data, (3) determine the proportion of patients demonstrating features related to $22 \mathrm{q} 11$ deletion syndrome (22q11DS) status (DiGeorge syndrome), and (4) determine the patient, clinical (including features related to 22q11DS status), and socioeconomic characteristics associated with scores of the different domains of the FHS questionnaires.

\section{METHODS}

\section{Patients and Questionnaires}

Between January 1987 and December 1997, patients with IAA admitted to a CHSS institution within 30 days of birth were prospectively enrolled by 29 CHSS member institutions (Appendix E1). IAA was defined via the operative note as a complete discontinuity or a nonpatent fibrous strand in the transverse arch or aortic isthmus. Patients who did not undergo arch repair were excluded (ie, died preintervention, aborted procedure, palliation, transplant). Medical and surgical management strategies were selected by the enrolling institution based on surgeon and institutional experience and preference.

During annual cross-sectional follow-up (08/09-08/10), a copy of the CHQ-CF87 was sent to all surviving patients $<18$ years old and the SF36 to all surviving patients $\geq 18$ years old at the time of the mailing. All patients also received a questionnaire developed by the CHSS related to current 22q11DS status and features. If no response was received within 6 weeks of initial mailing, a reminder was mailed, followed by 2 attempts to complete telephone follow-up, in addition to reminder e-mails if addresses were available.

For a flow chart of patients in the study, see Figure 1. Note 22 questionnaires were primarily completed by caregivers, secondary to inability of the patient to complete the questionnaire, potentially, but not necessarily indicating cognitive impairment. These were excluded. As a result, our study included 117 of 278 patients $(42 \%)$ at a median age of 19 years (range $13-23$, and mean age $19 \pm 3$ years). We also had 141 of 278 (51\%) patients return a 22q11DS questionnaire (2 patients who completed the CHQ-CF87 and 3 who completed the SF-36, did not complete the 22q11DS questionnaire; in addition, some patients' families only completed the 22q11DS questionnaire). Patient characteristics and cardiac morphology (responders and nonresponders) are summarized in Appendix E2.

\section{CHQ-CF87 and SF-36}

Both the CHQ-CF87 and the SF-36 are highly validated patient completed questionnaires focusing on an individual's subjective perception of his/her health, as opposed to parental perceptions. ${ }^{16-20}$ In both questionnaires, greater domain scores indicate better self-perceived function. In both questionnaires, respondents are also asked to rate their change in health in comparison with 1 year ago. Of note, the SF-36 contains 2 psychometrically based scores, the Physical Component Summary and the Mental Component Summary, which are calculated from the domain scores within the SF-36. Table 1 presents the features of the CHQ-CF87 and SF36.

\section{2q11DS Questionnaire}

The CHSS qualitative 22q11DS questionnaire was developed to assist us in determining whether patients exhibit any of the features commonly associated with 22q11DS, despite a recorded diagnosis 


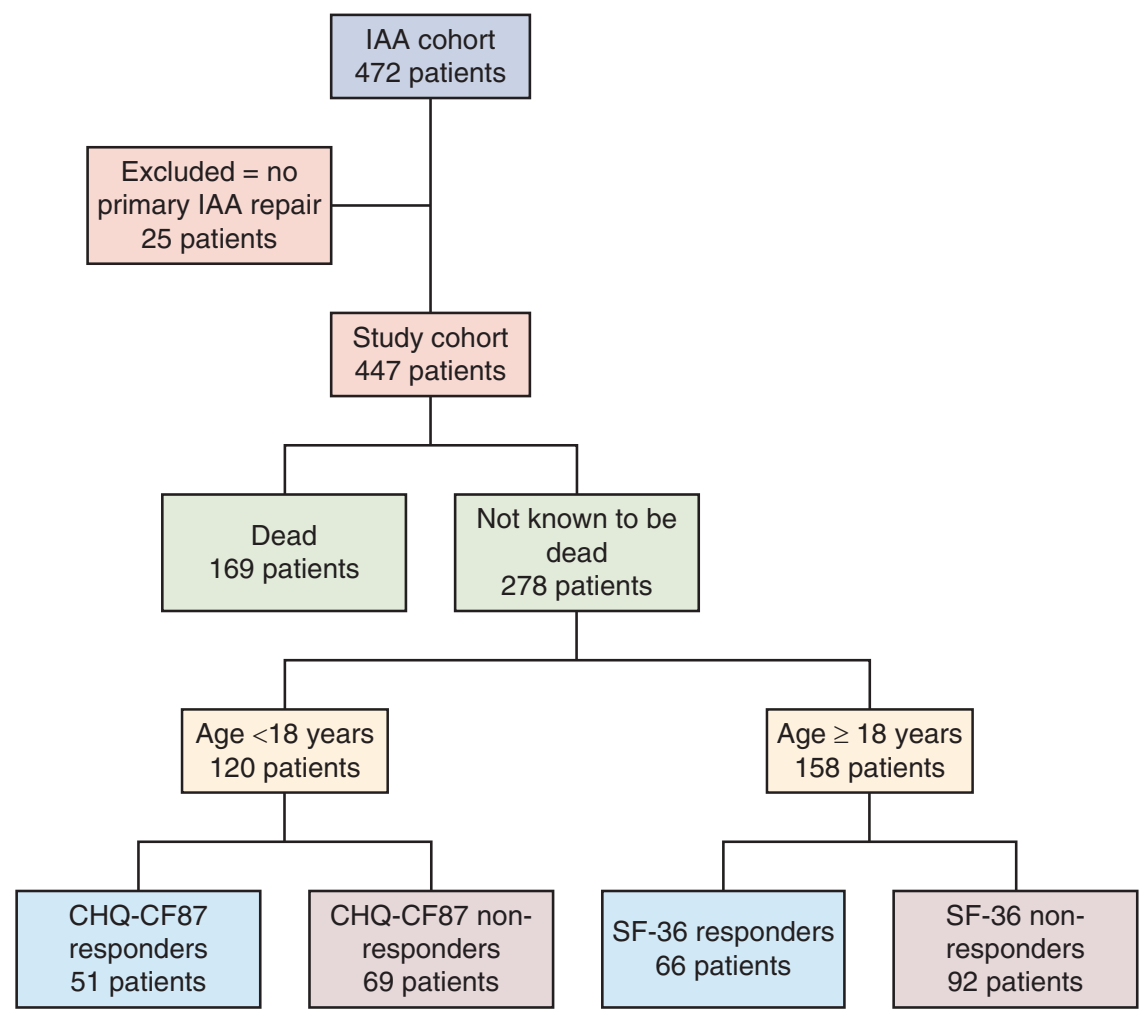

FIGURE 1. Flow chart of patients in study. IAA, Interrupted aortic arch; $C H Q-C F 87$, Child Health Questionnaire-Child Form 87; $S F-36$, Medical Outcomes Study Short Form-36 Health Survey version 2.

(see Appendix E3 for the details regarding questionnaire development and validation of the questionnaire, raw response data, and a summary of findings). When many patients were initially diagnosed and evaluated for
IAA, genetic testing was not widely available, and because of the variable phenotype associated with 22q11DS, many patients may not have been diagnosed clinically with this condition.

TABLE 1. Features of the CHQ-CF87 and the SF-36 questionnaires

\begin{tabular}{|c|c|c|}
\hline & CHQ-CF87 & SF-36 \\
\hline Focus & Generic & Generic \\
\hline Number of items (questions) & 87 & 36 \\
\hline Age, $y$ & 10 to $<18$ & $\geq 18$ \\
\hline Number of domains & 13 & 8 \\
\hline Score & Range $0-100$ & 50 is the average score or norm \\
\hline Number of psychometrically-based scores (calculated from the other domains) & 0 & 2 \\
\hline Names of psychometrically-based scores & N/A & $\begin{array}{l}\text { Physical Component Summary } \\
\text { Mental Component Summary }\end{array}$ \\
\hline Domains used to calculate each psychometrically based score & N/A & $\begin{array}{l}\text { Physical Component Summary } \\
\text { Physical Functioning } \\
\text { Role-Physical } \\
\text { (freedom from) Bodily Pain } \\
\text { General Health } \\
\text { Mental Component Summary } \\
\text { Vitality } \\
\text { Social Functioning } \\
\text { Role-Emotional } \\
\text { Mental Health }\end{array}$ \\
\hline
\end{tabular}

CHQ-CF87, Child Health Questionnaire-Child Form 87; SF-36, Medical Outcomes Study Short Form-36 Health Survey version 2; N/A, not available. 


\section{Additional Data Collection}

See Appendix E4.

\section{Consent}

Informed consent was obtained from patients. Ethics approval for the CHSS was obtained from the Research Ethics Board at SickKids, in addition to obtaining local institutional approval. Institutional review board approval number, initial study approval date, and expiration date are 0019990052, October 27, 2009/November 5, 2009, and March 13, 2019, respectively.

\section{Statistical Analysis}

Standard descriptive and comparative statistics were performed. $\mathrm{Z}$ scores were calculated for both FHS questionnaires to examine deviations from normal and assess degree of deviation between adolescents and young adults. FHS scores were compared with normative data using single sample $t$ tests against a hypothesized mean. Multivariable linear regression with bootstrap bagging was performed using selected variables in Appendix E2 and the 22q11DS questionnaire. Missing data were imputed using the technique of mean imputation. Final multivariable models for each FHS score were obtained through stepwise multivariable regression modeling, with backward selection of the variables selected using bootstrapping.

See Appendix $E 4^{20-22}$ for detailed information regarding consent and the statistical methods.

\section{RESULTS \\ Comparison With Normative Data}

CHQ-CF87 scores were significantly different in 2 of 9 categories when compared with normative data, with a greater score for Mental Health $(P=.03)$ and for (freedom from) Bodily Pain $(P<.0001)$ (Table 2, Figure 2, A). Patients who underwent the SF-36 were compared with normative patients aged 18 to 24 years (Table 2, Figure 2, B). SF-36 responders were found to have greater scores for 4 of 10 domains, specifically the Mental Component Summary $(P=.04)$, (freedom from) Bodily Pain $(P=.0002)$, Vitality $(P=.0002)$, and Mental Health $(P=.01)$. Patient scores were only significantly

TABLE 2. Questionnaire scores with published norms and $\mathrm{z}$ scores

\begin{tabular}{|c|c|c|c|c|}
\hline CHQ-CF 87 domains & $\begin{array}{c}\text { IAA patients }<18 \text { y }(n=51) \\
\text { mean } \pm \text { standard deviation, } m=\text { missing }\end{array}$ & Published norms, $\mathrm{n}=\mathbf{2 3 2}$ & $P$ value & Z score \\
\hline Global Health (GGH) & $77.2 \pm 17.2, \mathrm{~m}=2$ & - & - & - \\
\hline Physical Functioning (PF) & $86.6 \pm 15.6, \mathrm{~m}=1$ & $88.8 \pm 14.0$ & .3 & -0.2 \\
\hline Role/Social Limitations-Emotional (RE) & $85.6 \pm 20.7, \mathrm{~m}=1$ & $85.9 \pm 21.0$ & .9 & -0.02 \\
\hline Role/Social Limitations-Behavioral (RB) & $88.0 \pm 25.3, \mathrm{~m}=2$ & $86.5 \pm 21.5$ & .7 & 0.07 \\
\hline Role/Social Limitations-Physical (RP) & $92.3 \pm 16.7, \mathrm{~m}=2$ & $88.3 \pm 21.0$ & .1 & 0.2 \\
\hline (Freedom from) Bodily Pain (BP) & $87.8 \pm 19.3, \mathrm{~m}=1$ & $74.4 \pm 23.1$ & $<.0001$ & 0.6 \\
\hline Behavior (BE) & $73.0 \pm 16.5, \mathrm{~m}=1$ & $76.6 \pm 14.6$ & .1 & 0.1 \\
\hline Global Behavior (GBE) & $71.0 \pm 27.6, \mathrm{~m}=0$ & - & - & - \\
\hline Mental Health (MH) & $77.6 \pm 15.2, \mathrm{~m}=1$ & $72.7 \pm 16.0$ & .03 & 0.7 \\
\hline Self Esteem (SE) & $79.3 \pm 15.6, \mathrm{~m}=2$ & $81.8 \pm 15.8$ & .3 & 0.3 \\
\hline General Health Perceptions (GH) & $64.5 \pm 14.8, \mathrm{~m}=2$ & $66.4 \pm 14.6$ & .4 & 0.3 \\
\hline Family Activities (FA) & $80.0 \pm 23.8, \mathrm{~m}=2$ & - & - & - \\
\hline Family Cohesion (FC) & $73.9 \pm 22.6, \mathrm{~m}=3$ & - & - & - \\
\hline SF-36 domains & $\begin{array}{c}\text { IAA patients }>18 \mathrm{y} \\
(\mathrm{n}=66) \\
\text { mean } \pm \text { standard deviation, } \\
\mathbf{m}=\text { missing }\end{array}$ & $\begin{array}{c}\text { Published norms } \\
\text { males and females } \\
\text { ages 18-24 y, } n=216 \text { except } \\
\text { Mental Health where } n=215\end{array}$ & $P$ value & Z score \\
\hline Physical Component Summary (PF/RP/BP/GH) & $52.4 \pm 7.5, \mathrm{~m}=3$ & $53.5 \pm 9.2$ & .3 & -0.1 \\
\hline Mental Component Summary (VT/SF/RE/MH) & $49.3 \pm 12.0, \mathrm{~m}=3$ & $46.1 \pm 13.3$ & .04 & 0.2 \\
\hline Physical Functioning (PF) & $50.7 \pm 8.0, \mathrm{~m}=1$ & $53.2 \pm 9.7$ & .02 & -0.3 \\
\hline Role-Physical (RP) & $50.9 \pm 8.6, \mathrm{~m}=1$ & $52.8 \pm 9.6$ & .09 & -0.2 \\
\hline (Freedom from) Bodily Pain (BP) & $55.9 \pm 8.0, \mathrm{~m}=1$ & $52.0 \pm 10.6$ & .0002 & 0.4 \\
\hline General Health (GH) & $49.2 \pm 10.9, \mathrm{~m}=2$ & $49.7 \pm 11.8$ & .7 & -0.04 \\
\hline Vitality (VT) & $52.6 \pm 11.3, \mathrm{~m}=2$ & $47.0 \pm 11.7$ & .0002 & 0.5 \\
\hline Social Functioning (SF) & $49.1 \pm 10.0, \mathrm{~m}=2$ & $49.2 \pm 12.3$ & .9 & -0.009 \\
\hline Role-Emotional (RE) & $49.0 \pm 11.8, \mathrm{~m}=2$ & $49.8 \pm 12.5$ & .6 & -0.06 \\
\hline Mental Health (MH) & $50.7 \pm 11.8, \mathrm{~m}=2$ & $46.9 \pm 13.0$ & .01 & 0.3 \\
\hline
\end{tabular}

CHQ-CF87, Child Health Questionnaire-Child Form 87; IAA, interrupted aortic arch; SF-36, Medical Outcomes Study Short Form-36 Health Survey version 2. 


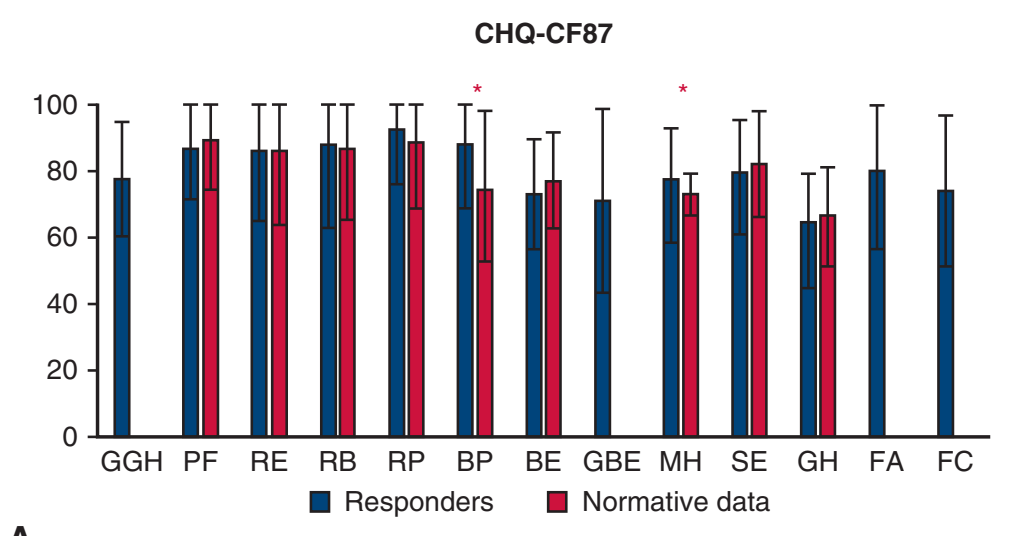

A

SF-36

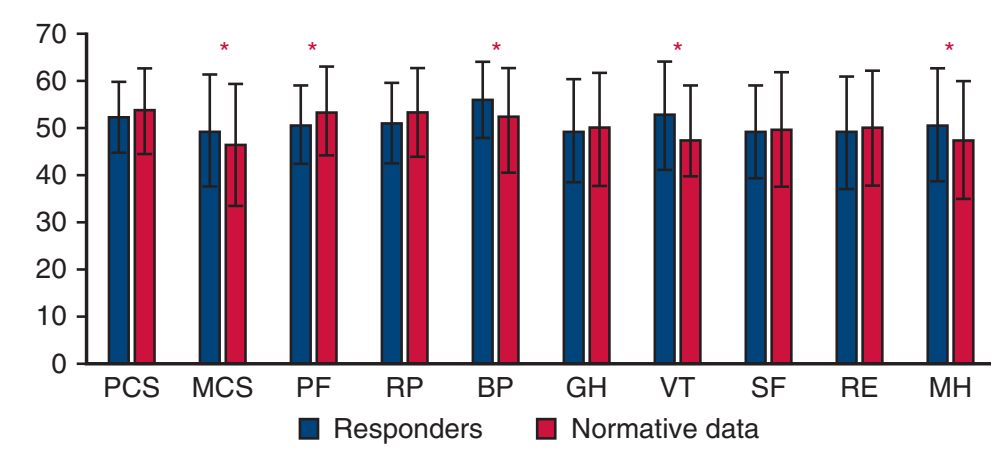

B

FIGURE 2. Comparison of CHQ-CF87 and SF-36 data to normative data. A, Comparison for CHQ-CF87. CHQ-CF87, Child Health Questionnaire-Child Form 87; GGH, Global Health; $P F$, Physical Functioning; $R E$, Role/Social Limitations-Emotional; $R B$, Role/Social Limitations-Behavioral; $R P$, Role/Social Limitations-Physical; $B P$, (Freedom from) Bodily Pain; $B E$, Behavior; $G B E$, Global Behavior; $M H$, Mental Health; $S E$, Self-Esteem; $G H$, General Health Perceptions; FA, Family Activities; FC, Family Cohesion. B, Comparison for SF-36. SF-36, Medical Outcomes Study Short Form-36 Health Survey version 2; PCS, Physical Component Summary; MCS, Mental Component Summary; RP, Role-Physical; GH, General Health Perceptions; RE, Role-Emotional; VT, Vitality; SF, Social Functioning.

lower for the Physical Functioning domain of the SF-36 $(P=.02)$.

\section{Comparisons of $\mathbf{Z}$ Scores With Normative Data}

There are 2 of 9 categories from the CHQ-CF87 in which the $\mathrm{z}$ scores were negative (Physical Functioning and Role/ Social Limitations-Emotional), whereas the remainder were positive ( 7 of 9). However, only 2 of these have statistically significant $P$ values ([freedom from] Bodily Pain $[P<.0001]$ and Mental Health $[P=.03])$. In contrast, when we examined the SF-36 scores, the majority of categories ( 6 of 10) have a slight trend to being below the normal values, and only 5 are statistically significantly different (with only Physical Functioning having a negative z score) (Table 2).

\section{Change in Health Status Compared With 1 Year Ago}

On both questionnaires, health status is graded using 5 choices. For both questionnaires, the majority of patients reported that their health is about the same now as 1 year ago
(55\% and $72 \%$ respectively), with more CHQ-CF87 patients doing worse (36\% [18/49]), and more SF-36 patients doing better $(25 \%[16 / 65])$ compared with 1 year ago (Table 3).

\section{Domain Associations for FHS Questionnaires}

Multivariable regression analyses were performed for each CHQ-CF87 and SF-36 domain score (Tables 4 and 5), and are further described herein. Although statistically significant, the percentage variation in CHQ-CF87 and SF-36 domain scores explained by the factors was highly variable, with adjusted $\mathrm{R}^{2}$ values ranging from $13 \%$ to $66 \%$ for the CHQ-CF87 and $9 \%$ to $51 \%$ for the SF-36. Of note, FHS was minimally related to IAA morphology and repair type.

\section{CHQ-CF87 Domain Associations}

Three main groups of variables were predominantly associated with CHQ-CF87 domains (Table 4). These were variables related to mental health, association with a genetic 
TABLE 3. Health status now versus 1 year ago from both functional health status questionnaires

\begin{tabular}{lcc}
\hline & $\begin{array}{c}\text { CHQ-CF87 } \\
\text { Change in } \\
\text { health }(\mathbf{C H}) \\
\mathbf{m}=\mathbf{2}\end{array}$ & $\begin{array}{c}\text { SF-36 } \\
\text { Reported health } \\
\text { transition (HT) } \\
\mathbf{m}=\mathbf{1}\end{array}$ \\
\hline Much better now than 1 y ago & $1 / 49(2 \%)$ & $4 / 65(6 \%)$ \\
\hline Somewhat better now than 1 y ago & $3 / 49(6 \%)$ & $12 / 65(18 \%)$ \\
\hline About the same now as 1 y ago & $27 / 49(55 \%)$ & $47 / 65(72 \%)$ \\
\hline Somewhat worse now than 1 y ago & $8 / 49(16 \%)$ & $1 / 67(2 \%)$ \\
\hline Much worse now than 1 y ago & $10 / 49(20 \%)$ & $1 / 65(2 \%)$ \\
\hline
\end{tabular}

The answers from both questionnaires are reported as raw data. $\mathrm{CHQ}$-CF87, Child Health Questionnaire-Child Form 87; SF-36, Medical Outcomes Study Short Form-36 Health Survey version 2.

condition, and those related to the total number of procedures patients underwent. The first of these groups were variables related to mental health status, specifically those from the 22q11DS questionnaire (discussed further herein). In all domains (except for Global Health, [freedom from] Bodily Pain, and General Health Perceptions), either the presence of mental health counseling or having taken medications for mental health problems was associated with decreased scores. The next group of variables related to genetic testing or the presence of a genetic condition and were also taken from the 22q11DS questionnaire. These variables also greatly affected scores and were associated with lower scores in the domains of (freedom from) Bodily Pain, Behavior, Self Esteem, and Family Activities. The third group of variables was the total number of procedures ("other" or catheter-based interventional), with more procedures being associated with lower domain scores. This was associated with Global Health, Role/Social Limitations-Physical, Mental Health, and Self Esteem.

Multiple other variables were significantly associated with CHQ-CF87 domain scores (Table 4). Of note, lower median neighborhood family income (calculated in US dollars) was adversely associated with the domains of Family Activities and Family Cohesion (ie, this was associated with lower scores). Features of 22q11DS (abnormal facial features, taking calcium supplements, having low calcium levels, having had speech therapy, having abnormal hearing, and having recurrent infections) were also associated with lower scores.

\section{SF-36 Domain Associations}

When we examined the results of the SF-36, 2 of the 3 groups of variables described above were widely associated with many domains of the SF-36 questionnaire (variables related to poor mental health and greater total number of procedures) (Table 5). Variables related to mental health taken from the 22q11DS questionnaire were associated with lower scores in 4 of the domains ([freedom from]
Bodily Pain, Vitality, Social Functioning, and Mental Health), and the Mental Component Summary score. As with the CHQ-CF87, a greater total number of procedures (arch, left ventricular outflow tract, or procedure of any type) was again associated with poorer scores in many domains. Shorter time to the last procedure was associated with poorer domain scores for Social Functioning and the Mental Component Summary score.

Several other features from the 22q11DS questionnaire were associated with lower scores, including recurrent childhood infections requiring medication or admission to hospital with the General Health domain, having a history of a low calcium level with the (freedom from) Bodily Pain domain, and having had behavioral problems in school with the Role-Emotional domain.

Finally, several other variables were associated with lower scores in various domains of the SF-36. These include the association of a lower median family income with the Physical Functioning and Role-Physical domain; presence of uncomplicated IAA with (freedom from) Bodily Pain and Social Functioning domain; lower weight at index repair with the Social Functioning domain; greater total number of medications with the Role-Emotional domain; and finally, younger age at questionnaire completion was adversely associated with the Mental Component Summary.

\section{Findings From the 22q11DS Questionnaire}

Please see Appendix E3 for findings from the 22q11DS questionnaire.

\section{Comparison of Responders With Nonresponders}

Although there were not many differences between responders and nonresponders for the CHQ-CF87, responders were less likely to have "other" medical problems $(27 \%$ vs $51 \%, P=.01)$, had greater total number of surgical procedures $(1.98 \pm 1.05$ vs $1.51 \pm 0.72, P=.01)$, and were more likely to have reoperative procedures with circulatory arrest ( $27 \%$ vs $10 \%, P=.01)$. The only difference between SF36 responders and nonresponders is that responders were younger $(19.9 \pm 1.3$ vs $20.5 \pm 1.7$ years, $P=.05)$. See Appendix E2 for a complete list of the variables compared.

\section{DISCUSSION Summary}

Our study of FHS demonstrates that patients with IAA generally perceive themselves as the same or better than their normal peers in multiple domains. The presence of factors related to the total number of procedures, time since last procedure, mental health, genetic testing or diagnosis, features potentially related to 22q11DS, and lower family income dominated over those related to anatomical details, repair type, and other variables. This suggests that variables associated with a recurrent well-being or health care interaction burden (eg, total number of procedures) or more 
TABLE 4. Summary of multiple regression analysis for independent factors associated with lower scores on individual domains for the Child Health Questionnaire-Child Form 87

\begin{tabular}{|c|c|c|c|c|}
\hline Variable & Parameter estimate & $P$ value & Reliability & $\mathbf{R}^{2} / \mathbf{a d j} \mathbf{R}^{2}$ \\
\hline Global Health (GGH) & & & & $0.17 / 0.14$ \\
\hline $\begin{array}{l}\text { Questionnaire reports that patient has been told by a doctor that } \\
\text { he/she has abnormal facial features }\end{array}$ & $12.11 \pm 5.11$ & .02 & $80 \%$ & \\
\hline Greater total number of "other" procedures & $7.06 \pm 3.45$ & .05 & $50 \%$ by cluster & \\
\hline Physical Functioning (PF) & & & & $0.52 / 0.48$ \\
\hline $\begin{array}{l}\text { Questionnaire reports that patient has had mental health } \\
\text { counseling by a social worker, psychologist, or psychiatrist }\end{array}$ & $16.20 \pm 3.63$ & $<.0001$ & $83 \%$ & \\
\hline $\begin{array}{l}\text { Questionnaire reports patient taking calcium supplements or } \\
\text { medications to correct calcium levels }\end{array}$ & $13.45 \pm 5.02$ & .01 & $61 \%$ & \\
\hline Greater total number of medications & $5.27 \pm 1.35$ & .0003 & $76 \%$ & \\
\hline Questionnaire reports that patient has had low calcium levels & $20.65 \pm 4.54$ & $>.0001$ & $62 \%$ & \\
\hline Lower weight at index IAA repair, $\mathrm{kg}$ (squared) & $5.63 \pm 2.00$ & .007 & $59 \%$ by cluster & \\
\hline Role/Social Limitations-Emotional (RE) & & & & $0.16 / 0.15$ \\
\hline $\begin{array}{l}\text { Questionnaire reports that patient has had mental health } \\
\text { counseling by a social worker, psychologist, or psychiatrist }\end{array}$ & $17.20 \pm 5.56$ & .003 & $63 \%$ & \\
\hline Role/Social Limitations-Behavioral (RB) & & & & $0.15 / 0.13$ \\
\hline $\begin{array}{l}\text { Questionnaire reports patient taking medication for mental health } \\
\text { problems }\end{array}$ & $21.64 \pm 7.47$ & .006 & $75 \%$ & \\
\hline Role/Social Limitations-Physical (RP) & & & & $0.47 / 0.41$ \\
\hline $\begin{array}{l}\text { Questionnaire reports that patient has had mental health } \\
\text { counseling by a social worker, psychologist, or psychiatrist }\end{array}$ & $13.97 \pm 3.91$ & .0009 & $76 \%$ & \\
\hline Elapsed time on bypass at index repair, min (inverse) & $1770.30 \pm 663.18$ & .01 & $74 \%$ by cluster & \\
\hline $\begin{array}{l}\text { Questionnaire reports patient taking calcium supplements or } \\
\text { medications to correct calcium levels }\end{array}$ & $12.15 \pm 4.73$ & .01 & $70 \%$ by cluster & \\
\hline Younger at questionnaire completion, y (inverse) & $863.04 \pm 293.42$ & .005 & $69 \%$ by cluster & \\
\hline Greater total number of catheter-based interventional procedures & $6.63 \pm 2.98$ & .03 & $50 \%$ by cluster & \\
\hline $\begin{array}{l}\text { (Freedom from) Bodily Pain (BP) } \\
\text { Questionnaire reports that patient has had speech therapy } \\
\text { Questionnaire reports that patient has a current diagnosis of } \\
\text { DiGeorge }\end{array}$ & $\begin{array}{l}22.82 \pm 5.70 \\
25.20 \pm 5.80\end{array}$ & $\begin{array}{r}.0002 \\
<.0001\end{array}$ & $\begin{array}{l}55 \% \\
50 \%\end{array}$ & $0.33 / 0.30$ \\
\hline Behavior (BE) & & & & $0.36 / 0.33$ \\
\hline $\begin{array}{l}\text { Questionnaire reports that patient has had mental health } \\
\text { counseling by a social worker, psychologist, or psychiatrist }\end{array}$ & $17.39 \pm 3.92$ & $<.0001$ & $51 \%$ & \\
\hline Patient reports having DNA testing & $11.85 \pm 4.22$ & .007 & $56 \%$ by cluster & \\
\hline Global Behavior (GBE) & & & & $0.40 / 0.38$ \\
\hline $\begin{array}{l}\text { Questionnaire reports patient taking medication for mental health } \\
\text { problems }\end{array}$ & $33.04 \pm 7.03$ & $<.0001$ & $55 \%$ & \\
\hline Presence of other medical problems & $20.36 \pm 6.84$ & .005 & $54 \%$ by cluster & \\
\hline Mental Health (MH) & & & & $0.70 / 0.66$ \\
\hline $\begin{array}{l}\text { Questionnaire reports that patient has had mental health } \\
\text { counseling by a social worker, psychologist, or psychiatrist }\end{array}$ & $18.95 \pm 2.84$ & $<.0001$ & $94 \%$ & \\
\hline Absence of an anomalous right subclavian & $9.95 \pm 3.00$ & .002 & $68 \%$ & \\
\hline Greater total number of medications & $4.76 \pm 1.11$ & $<.0001$ & $63 \%$ & \\
\hline Presence of other medical problems & $12.56 \pm 2.85$ & $<.0001$ & $61 \%$ & \\
\hline Questionnaire reports having abnormal hearing test result & $12.65 \pm 2.99$ & .0001 & $51 \%$ & \\
\hline Greater total number of catheter-based interventional procedures & $8.17 \pm 2.16$ & .0005 & $57 \%$ by cluster & \\
\hline Self Esteem (SE) & & & & $0.40 / 0.37$ \\
\hline $\begin{array}{l}\text { Questionnaire reports that patient has had mental health } \\
\text { counseling by a social worker, psychologist, or psychiatrist }\end{array}$ & $13.39 \pm 3.57$ & .0005 & $56 \%$ & \\
\hline Questionnaire reports having a diagnosis of a genetic condition & $11.79 \pm 3.76$ & .003 & $65 \%$ by cluster & \\
\hline Higher total number of "other" procedures & $4.90 \pm 1.87$ & .01 & $64 \%$ by cluster & \\
\hline
\end{tabular}


TABLE 4. Continued

\begin{tabular}{|c|c|c|c|c|}
\hline Variable & Parameter estimate & $P$ value & Reliability & $\mathbf{R}^{2} / \mathbf{a d j} \mathbf{R}^{2}$ \\
\hline General Health Perceptions (GH) & & & & $0.16 / 0.14$ \\
\hline $\begin{array}{l}\text { Questionnaire reports recurrent childhood infections requiring } \\
\text { medication or admission to hospital }\end{array}$ & $12.99 \pm 4.23$ & .004 & $59 \%$ & \\
\hline Family Activities (FA) & & & & $0.53 / 0.49$ \\
\hline $\begin{array}{l}\text { Questionnaire reports that patient has had mental health } \\
\text { counseling by a social worker, psychologist, or psychiatrist }\end{array}$ & $31.42 \pm 5.12$ & $<.0001$ & $77 \%$ & \\
\hline Questionnaire reports having a diagnosis of a genetic condition & $18.88 \pm 5.14$ & .0006 & $74 \%$ by cluster & \\
\hline Lower weight at index IAA repair, kg (squared) & $8.08 \pm 2.95$ & .009 & $64 \%$ by cluster & \\
\hline Lower median family income for (USD) neighborhood (inverse) & $66.96 \pm 20.97$ & .003 & $61 \%$ by cluster & \\
\hline Family Cohesion (FC) & & & & $0.38 / 0.33$ \\
\hline Presence of bicuspid aortic valve & $32.08 \pm 6.72$ & $<.0001$ & $82 \%$ & \\
\hline Absence of an anomalous right subclavian & $17.21 \pm 6.55$ & .01 & $61 \%$ & \\
\hline $\begin{array}{l}\text { Questionnaire reports that patient has had mental health } \\
\text { counseling by a social worker, psychologist, or psychiatrist }\end{array}$ & $17.40 \pm 5.64$ & .003 & $52 \%$ & \\
\hline Lower median family income for neighborhood USD) (inverse) & $71.35 \pm 23.46$ & .004 & $65 \%$ by cluster & \\
\hline
\end{tabular}

$I A A$, Interrupted aortic arch; USD, United States dollars.

immediacy (eg, time since last procedure) and a greater potential impact with respect to the patient (eg, mental health) have a stronger influence on FHS. Two variables associated with poor domain scores help to confirm this; shorter time since last procedure and more procedures (which may be a surrogate for more recent procedures). See Video 1 for a summary of our study.

\section{Comparison With Normative Data}

The only domain from both questionnaires in which patients had significantly lower scores than their normal peers was Physical Functioning for the SF-36. All other domains showed no significant differences, or significantly greater scores. Similar to other studies, our patients had greater scores in the (freedom from) Bodily Pain domain (ie, less pain). ${ }^{4,6,8,9,14,23}$ These greater scores might be secondary to many factors, including the notion that these children have increased resiliency and strength after having had an operation for congenital heart disease (CHD), or that having CHD gives children a different reference point for comparison.

Patients with IAA generally perceive themselves as having the same or greater FHS than their peers, possibly attributed to several concepts reported in the literature: the disability paradox; response shift; and sense of coherence. ${ }^{24,25}$ The disability paradox results from a conflict in perception about these individuals with IAA. Although they are often perceived by external observers to have an undesirable daily life, they feel that they experience good FHS, as demonstrated by their scores. Response shift is the change in internal standards and values due to a redefinition of "good FHS." ${ }^{26,27}$ Patients with IAA may have developed internal values of health that are different from healthy individuals, leading them to rate themselves the same or greater than their normal peers. ${ }^{24}$ Finally, a sense of coherence can be defined as a gauge of an individual's view on the world, which is improved by a sense of being highly comprehensible, manageable, and meaningful. ${ }^{24,28}$ Patients who grow up with CHD may have learned to cope with their disease (ie, have made it more manageable) and have an increased appreciation and meaningfulness associated with their life, as they have had it threatened by an illness that required major surgery. ${ }^{24}$

\section{Demographic and Clinical Factors}

In our multivariable analyses, adjusted $\mathrm{R}^{2}$ values ranged from $9 \%$ to $66 \%\left(\mathrm{R}^{2}=0.10-0.70\right)$, which indicates that in some cases a large part of the variation in a domain score can be explained by the variables we have tested (a high $\mathrm{R}^{2}$ ), whereas in others the opposite was true (a low $\mathrm{R}^{2}$ ). In a past publication by Culbert and colleagues ${ }^{14}$ whereby each domain was evaluated for associations, $\mathrm{R}^{2}$ values for models for the CHQ-CF87 domains ranged from 0.0240.26 . We could not find publications reporting $\mathrm{R}^{2}$ values for the SF-36 domains. In most domains, the variables we tested place our $\mathrm{R}^{2}$ values toward the upper values of past ranges or above those in past publications. However, we still have not been able to find the combination of explanatory variables allowing us to explain a larger proportion of the variation. We would likely benefit from including other information in our dataset which we did not have, possibly related to current symptoms and exercise capacity.

\section{Adolescents Compared With Adults}

When we compare the health status of adolescents (CHQCF87) and young adults (SF-36), now versus 1 year ago, in adolescents a small proportion of patients seemed to be getting worse (somewhat worse or much worse), whereas in 
TABLE 5. Summary of multiple regression analysis for independent factors associated with lower scores on individual domains for the Short Form-36 Health Survey

\begin{tabular}{|c|c|c|c|c|}
\hline Variable & Parameter estimate & $P$ value & Reliability & $\mathbf{R}^{2} / \mathbf{a d j} \mathbf{R}^{2}$ \\
\hline Physical Component Summary (PCS) & & & & $0.11 / 0.10$ \\
\hline Greater total number of arch procedures & $2.41 \pm 0.85$ & .007 & $71 \%$ by cluster & \\
\hline Mental Component Summary (MCS) & & & & $0.47 / 0.44$ \\
\hline $\begin{array}{l}\text { Questionnaire reports that patient has had mental health } \\
\text { counseling by a social worker, psychologist, or psychiatrist }\end{array}$ & $14.17 \pm 2.65$ & $<.0001$ & $95 \%$ & \\
\hline Younger age at questionnaire completion, y (inverse) & $879.63 \pm 371.25$ & .02 & $60 \%$ by cluster & \\
\hline Shorter time since last procedure, y (inverse) & $94.64 \pm 28.65$ & .001 & $52 \%$ by cluster & \\
\hline Physical Functioning (PF) & & & & $0.10 / 0.09$ \\
\hline $\begin{array}{l}\text { Lower median family income for neighborhood (USD) } \\
\text { (inverse) }\end{array}$ & $30.81 \pm 11.60$ & .01 & $63 \%$ by cluster & \\
\hline Role-Physical (RP) & & & & $0.17 / 0.15$ \\
\hline Greater total number of arch procedures & $2.93 \pm 0.97$ & .004 & $59 \%$ & \\
\hline $\begin{array}{l}\text { Lower median family income for neighborhood (USD) } \\
\text { (inverse) }\end{array}$ & $25.52 \pm 12.00$ & .04 & $61 \%$ by cluster & \\
\hline (Freedom from) Bodily Pain (BP) & & & & $0.52 / 0.49$ \\
\hline $\begin{array}{l}\text { Questionnaire reports that patient has had mental health } \\
\text { counseling by a social worker, psychologist, or psychiatrist }\end{array}$ & $8.57 \pm 1.69$ & $<.0001$ & $87 \%$ & \\
\hline Presence of uncomplicated IAA & $5.15 \pm 1.87$ & .008 & $78 \%$ & \\
\hline Questionnaire reports that patient has had low calcium levels & $5.13 \pm 1.93$ & .01 & $54 \%$ & \\
\hline Greater total number of procedures of any type & $1.73 \pm 0.41$ & $<.0001$ & $63 \%$ by cluster & \\
\hline General Health $(\mathrm{GH})$ & & & & $0.21 / 0.18$ \\
\hline $\begin{array}{l}\text { Questionnaire reports recurrent childhood infections } \\
\text { requiring medication or admission to hospital (present) }\end{array}$ & $10.45 \pm 3.14$ & .002 & $50 \%$ & \\
\hline Greater total number of arch procedures & $3.07 \pm 1.20$ & .01 & $59 \%$ by cluster & \\
\hline Vitality (VT) & & & & $0.32 / 0.31$ \\
\hline $\begin{array}{l}\text { Questionnaire reports that patient has had mental health } \\
\text { counseling by a social worker, psychologist, or psychiatrist }\end{array}$ & $14.72 \pm 2.71$ & $<.0001$ & $94 \%$ & \\
\hline Social Functioning (SF) & & & & $0.55 / 0.51$ \\
\hline $\begin{array}{l}\text { Questionnaire reports that patient has had mental health } \\
\text { counseling by a social worker, psychologist, or psychiatrist }\end{array}$ & $11.96 \pm 2.02$ & $<.0001$ & $87 \%$ & \\
\hline Presence of uncomplicated IAA & $5.18 \pm 2.27$ & .03 & $68 \%$ & \\
\hline $\begin{array}{l}\text { Greater total number of left ventricular outflow tract } \\
\text { procedures }\end{array}$ & $2.53 \pm 1.05$ & .02 & $55 \%$ by cluster & \\
\hline Lower weight at index IAA repair, $\mathrm{kg}$ (inverse) & $57.93 \pm 16.38$ & .0008 & $56 \%$ by cluster & \\
\hline Shorter time since last procedure, y (inverse) & $114.58 \pm 22.75$ & $<.0001$ & $60 \%$ by cluster & \\
\hline Role-Emotional (RE) & & & & $0.32 / 0.29$ \\
\hline $\begin{array}{l}\text { Questionnaire reports patient has had a behavioral problem in } \\
\text { school }\end{array}$ & $9.04 \pm 3.41$ & .01 & $58 \%$ & \\
\hline Greater total number of medications & $3.17 \pm 0.86$ & .0005 & $52 \%$ & \\
\hline Greater total number of arch procedures & $4.41 \pm 1.22$ & .0006 & $80 \%$ by cluster & \\
\hline Mental Health (MH) & & & & $0.34 / 0.33$ \\
\hline $\begin{array}{l}\text { Questionnaire reports that patient has had mental health } \\
\text { counseling by a social worker, psychologist, or psychiatrist }\end{array}$ & $15.87 \pm 2.75$ & $<.0001$ & $95 \%$ & \\
\hline
\end{tabular}

IAA, Interrupted aortic arch; USD, United States dollars.

young adults a small proportion was doing better (somewhat better or much better). In both groups, the majority thought their health was about the same now as 1 year ago $(55 \%$ vs $72 \%)$, although the proportion was greater for young adults. For the adolescents who completed this questionnaire (12.9-17.8 years of age), we speculate that a small proportion feel that their condition is getting worse, as at their age they are more aware of differences when compared with their normal peers. We speculate that more young adults who completed the questionnaire (18.0-23.2 years of age) feel they are doing better for a similar reason of increased stability as they mature into their 


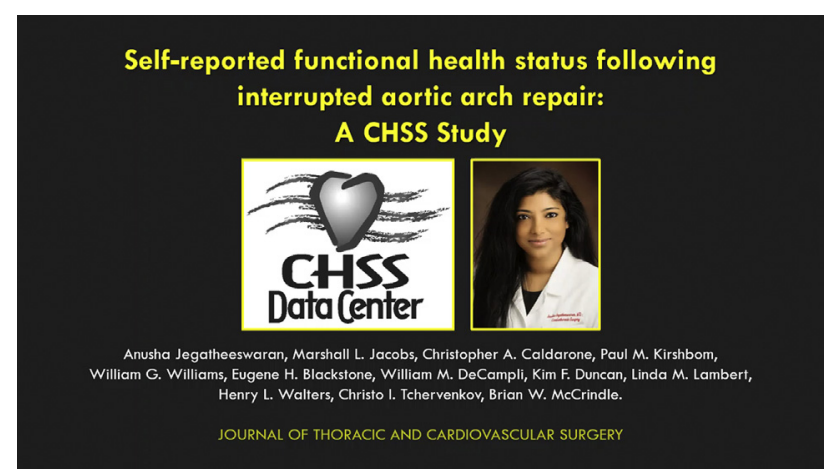

VIDEO 1. Self-reported functional health status following interrupted aortic arch repair: A Congenital Heart Surgeons' Society Study. Video available at: https://www.jtcvs.org/article/S0022-5223(19)30001-7/fulltext.

adult roles. Another reason that the data may be demonstrating these differences is the young adult population may be self-selecting or evolving to represent those who are doing better or are more stable with respect to their health (attrition of sicker patients), whereas the adolescent population is still evolving.

Results from the CHQ-CF87 show only significant differences in 2 domains ([freedom from] Bodily Pain and Mental Health), in both of which patients with IAA score greater than their normal peers. In comparison, on the SF-36, patients with IAA score greater in 1 component score (Mental Component Summary) and 3 domains ([freedom from] Bodily Pain, General Health, and Mental Health), with only Physical Functioning having a significantly lower score. These results may demonstrate that adult patients with IAA tend to feel they are doing even better compared with their adolescent counterparts, although these results are not from the same questionnaire, preventing direct comparison. Only with respect to Physical Functioning do young adults fare worse; however, this may be the result of multiple causes and should be the focus of future work. We can speculate that this results from fewer patients transitioning to adult care, with transition occurring at a later age or not at all. We can also hypothesize that their poorer Physical Functioning scores may be secondary to patients not being medically optimized because they have not transitioned to adult care and are not receiving appropriate care. This may also be related to a change in perception as patients age, with patients older than 18 years of age having a different perspective than their younger counterparts with regard to normal physical functioning once they become more independent and are able to better compare themselves with their peers.

\section{Study Limitations}

The questionnaire-based limitations include the following: (1) that these questionnaires are performed in a cross-sectional fashion, and we do not know how FHS varies daily and over longer periods; (2) we have used generic questionnaires that may overlook important disease-specific measures in this population but allow for comparison with normal reference populations (we also chose to use a generic questionnaire because there was no other FHS data available on this population); (3) since both questionnaires are self-reported, cognitively impaired patients who could not complete the questionnaire were excluded, likely biasing results as these patients likely have worse FHS; and (4) the 22q11DS questionnaire was developed for use qualitatively with validation via cognitive debriefing; however, results have not been validated against a normal population. The study-based limitations and sources of bias include the following: (1) the CHSS cohort likely does not contain every patient eligible from each CHSS institution, potentially contributing to selection bias; (2) the response rate was suboptimal, although good for survey methodology, and thus results may not reflect those of the entire population (although differences were examined between responders and nonresponders); (3) CHQ-CF87 responders were less likely to have "other" medical problems, more surgical procedures, and more reoperations with circulatory arrest, potentially providing us with more current contact information and thus the ability to contact them; (4) the overall mortality in our cohort (enrolled 1987-1997) was 38\% (169/447), and because mortality is better in the current era, our FHS results could also differ in a contemporary cohort ${ }^{15,22,29-31}$; and (5) each assessment of FHS should be appreciated as only part of a larger picture of well-being that includes more traditional outcome data and objective data such as exercise testing.

Although the denominator we used was 278 patients, 6 patients previously refused participation, and the CHSS Data Center could not directly contact 56 patients because of regulatory issues (with minimal follow-up by institutions). Thus, the denominator could have been lowered, increasing response rates.

\section{Future Directions}

Areas for extension of this work include (1) combining these data with objective FHS measures (eg, exercise test data), (2) repeated assessment of FHS to assess time/event related changes, (3) using cardiac specific questionnaires, and (4) comparison with other CHD groups to appreciate differences related to diagnosis and complexity.

\section{CONCLUSIONS}

FHS in adolescence and early adulthood is predominantly affected by morbidities associated with (but not unique to) 22q11DS, psychosocial issues, and recurrent medical procedures, rather than specific details related to underlying morphology and initial surgical repair. This supports what we established in our previous paper, that IAA is a chronic disease. However, patients with IAA also 
generally perceived themselves as having the same or greater FHS than their normal peers. From a clinical perspective, strategies to reduce the need for reinterventions should be a focus of surgical efforts, as patients with recurrent medical procedures tend to fare worse with respect to FHS. In light of our findings, preoperative counseling by surgeons and cardiologists should potentially stress ongoing evaluation of genetic and mental health issues, which may be an important component of care, especially in the transition from adolescence to early adulthood. Longitudinal FHS assessment is needed via prospective repeated measurement to detect normal variation, deteriorations related to increasing medical complexity, changes associated with admissions and procedures, and variation associated with mature adult roles and responsibilities.

\section{Conflict of Interest Statement}

Authors have nothing to disclose with regard to commercial support.

\section{References}

1. Leidy NK. Functional status and the forward progress of merry-go-rounds: toward a coherent analytical framework. Nurs Res. 1994;43:196-202.

2. Wilson IB, Cleary PD. Linking clinical variables with health-related quality of life. A conceptual model of patient outcomes. JAMA. 1995;273:59-65.

3. Spijkerboer AW, Utens EM, De Koning WB, Bogers AJ, Helbing WA, Verhulst FC. Health-related quality of life in children and adolescents after invasive treatment for congenital heart disease. Qual Life Res. 2006;15:663-73.

4. McCrindle BW, Williams RV, Mitchell PD, Hsu DT, Paridon SM, Atz AM, et al. Relationship of patient and medical characteristics to health status in children and adolescents after the Fontan procedure. Circulation. 2006;113:1123-9.

5. Landolt MA, Valsangiacomo Buechel ER, Latal B. Health-related quality of life in children and adolescents after open-heart surgery. J Pediatr. 2008;152: 349-55.

6. McCrindle BW, Zak V, Pemberton VL, Lambert LM, Vetter VL, Lai WW, et al. Functional health status in children and adolescents after Fontan: comparison of generic and disease-specific assessments. Cardiol Young. 2014;24:469-77.

7. Dulfer K, Bossers SS, Utens EM, Duppen N, Kuipers IM, Kapusta L, et al. Does functional health status predict health-related quality of life in children after Fontan operation? Cardiol Young. 2016;26:459-68.

8. Hickey EJ, Veldtman G, Bradley TJ, Gengsakul A, Webb G, Williams WG, et al. Functional health status in adult survivors of operative repair of tetralogy of Fallot. Am J Cardiol. 2012;109:873-80.

9. Knowles R, Veldtman G, Hickey EJ, Bradley T, Gengsakul A, Webb GD, et al. Functional health status of adults with tetralogy of Fallot: matched comparison with healthy siblings. Ann Thorac Surg. 2012;94:124-32.

10. Ekman-Joelsson BM, Berntsson L, Sunnegardh J. Quality of life in children with pulmonary atresia and intact ventricular septum. Cardiol Young. 2004;14:615-21.

11. Hövels-Gürich HH, Konrad K, Wiesner M, Minkenberg R, HerpertzDahlmann B, Messmer BJ, et al. Long term behavioural outcome after neonatal arterial switch operation for transposition of the great arteries. Arch Dis Child. 2002;87:506-10.
12. Larsen SH, McCrindle BW, Jacobsen EB, Johnsen SP, Emmertsen K Hjortdal VE. Functional health status in children following surgery for congenital heart disease: a population-based cohort study. Cardiol Young. 2010;20:631-40.

13. Dunbar-Masterson C, Wypij D, Bellinger DC, Rappaport LA, Baker AL Jonas RA, et al. General health status of children with D-transposition of the great arteries after the arterial switch operation. Circulation. 2001;104:I138-42.

14. Culbert EL, Ashburn DA, Cullen-Dean G, Joseph JA, Williams WG Blackstone EH, et al. Quality of life of children after repair of transposition of the great arteries. Circulation. 2003;108:857-62.

15. Jegatheeswaran A, McCrindle BW, Blackstone EH, Jacobs ML, Lofland GK, Austin EH III, et al. Persistent risk of subsequent procedures and mortality in patients after interrupted aortic arch repair: a Congenital Heart Surgeons' Society study. J Thorac Cardiovasc Surg. 2010;140:1059-75.

16. Lewis CC, Pantell RH, Kieckhefer GM. Assessment of children's health status. Field test of new approaches. Med Care. 1989;27:S54-65.

17. Pal DK. Quality of life assessment in children: a review of conceptual and methodological issues in multidimensional health status measures. J Epidemiol Community Health. 1996;50:391-6.

18. Vivier PM, Bernier JA, Starfield B. Current approaches to measuring health outcomes in pediatric research. Curr Opin Pediatr. 1994;6:530-7.

19. Landgraf JM, Abetz L, Ware JE. Child Health Ouestionnaire (CHO): A User's Manual. Boston: The Health Institute, New England Medical Center; 1996.

20. Ware JE Jr, Kosinski M, Bjorner JB, Turner-Bowker DM, Gandek B, Maruish ME. User's Manual for the SF-36v2@ Health Survey. 2nd ed. Lincoln, RI: Quality Metric Incorporated; 2007.

21. Landgraf JM, Abetz LN. Functional status and well-being of children representing three cultural groups: initial self-reports using the CHQ-CF87. Psychol Health. 1997:12:839-54.

22. McCrindle BW, Tchervenkov CI, Konstantinov IE, Williams WG, Neirotti RA, Jacobs ML, et al. Risk factors associated with mortality and interventions in 472 neonates with interrupted aortic arch: a Congenital Heart Surgeons Society study. J Thorac Cardiovasc Surg. 2005;129:343-50.

23. van der Rijken RE, Maassen BA, Walk TL, Daniels O, Hulstijn-Dirkmaat GM Outcome after surgical repair of congenital cardiac malformations at school age. Cardiol Young. 2007;17:64-71.

24. Moons P, Van Deyk K, De Bleser L, Marquet K, Raes E, De Geest S, et al. Quality of life and health status in adults with congenital heart disease: a direct comparison with healthy counterparts. Eur J Cardiovasc Prev Rehabil. 2006;13:407-13.

25. Albrecht GL, Devlieger PJ. The disability paradox: high quality of life against all odds. Soc Sci Med. 1999;48:977-88.

26. Rapkin BD, Schwartz CE. Toward a theoretical model of quality-of-life appraisal: implications of findings from studies of response shift. Health Qual Life Outcomes. 2004:2:14.

27. Sprangers MA, Schwartz CE. Integrating response shift into health-related quality of life research: a theoretical model. Soc Sci Med. 1999;48:1507-15.

28. Antonovsky A. Unraveling the Mystery of Health: How People Manage Stress and Stay Well. San Francisco: Jossey-Bass; 1987

29. Brown JW, Ruzmetov M, Okada Y, Vijay P, Rodefeld MD, Turrentine MW. Outcomes in patients with interrupted aortic arch and associated anomalies: a 20year experience. Eur J Cardiothorac Surg. 2006;29:666-73; discussion 673-4.

30. Jonas RA. Management of interrupted aortic arch. Semin Thorac Cardiovasc Surg. 2015;27:177-88.

31. Shinkawa T, Jaquiss RD, Imamura M. Single institutional experience of interrupted aortic arch repair over 28 years. Interact Cardiovasc Thorac Surg. 2012;14 $551-5$.

Key Words: congenital heart disease, CHD, CHD interrupted arch, database, outcomes, quality of life, statistics, statistics regression analysis 


\section{APPENDIX E1. PARTICIPATING CONGENITAL HEART SURGEONS' SOCIETY INSTITUTIONS \\ Institution name \\ Canada \\ Hospital for Sick Children, Toronto, Ontario \\ Montreal Children's Hospital, Montreal, Quebec \\ International}

Heart Institute, Sao Paulo, Brazil

United States

University of Alabama at Birmingham, Birmingham, Ala

The Children's Hospital, Denver, Colo

Miami Children's Hospital, Miami, Fla

University of Miami, Miami, Fla

All Children's Hospital, St Petersburg, Fla

Loma Linda University Medical Center, Loma Linda, Calif

Children's Hospital of Los Angeles, Los Angeles, Calif

University of California, Los Angeles, School of Medicine, Center for Health Science, Los Angeles, Calif
Children's Hospital and Health Center, San Diego, Calif

University of California, San Francisco, Calif

Children's Memorial Hospital, Chicago, Ill

University of Chicago, Chicago, Ill

University of Iowa Hospitals and Clinics, Iowa City, Iowa

The Children's Hospital, Boston, Mass

Mott Hospital, Ann Arbor, Mich

Children's Hospital of Michigan, Detroit, Mich

University of Nebraska Medical Center and Children's Hospital, Omaha, Neb

Children's Hospital of Buffalo, Buffalo, NY

Columbia Presbyterian, New York, NY

Duke University Medical Center, Durham, NC

Children's Hospital Medical Center, Cincinnati, Ohio

Milton S. Hershey Medical Center, Hershey, Pa

The Children's Hospital of Philadelphia, Philadelphia, Pa

Children's Hospital of Pittsburgh, Pittsburgh, Penn

Medical University of South Carolina, Charleston, SC

Primary Children's Hospital, Salt Lake City, Utah 
APPENDIX E2. Patient demographic, morphologic, and procedure-related variables for responders and nonresponders of the CHQ-CF87 and SF-36

\begin{tabular}{|c|c|c|c|c|c|c|c|c|c|c|}
\hline \multirow[b]{2}{*}{ Variable } & \multicolumn{2}{|c|}{ CHQ-CF87, $n=51$} & \multicolumn{2}{|c|}{ CHQ-CF87 nonresponders, $n=69$} & \multirow[b]{2}{*}{$P$ value } & \multicolumn{2}{|r|}{ SF-36, $n=66$} & \multicolumn{2}{|c|}{ SF-36 nonresponders, $\mathbf{n}=\mathbf{9 2}$} & \multirow[b]{2}{*}{$P$ value } \\
\hline & $\begin{array}{l}\text { Number } \\
\text { (missing) }\end{array}$ & Value & $\begin{array}{l}\text { Number } \\
\text { (missing) }\end{array}$ & Value & & $\begin{array}{l}\text { Number } \\
\text { (missing) }\end{array}$ & Value & $\begin{array}{l}\text { Number } \\
\text { (missing) }\end{array}$ & Value & \\
\hline \multicolumn{11}{|l|}{$\begin{array}{c}\text { Patient demographic } \\
\text { information }\end{array}$} \\
\hline Male & $28(0)$ & $55 \%$ & $34(0)$ & $49 \%$ & .5 & $34(0)$ & $52 \%$ & $53(0)$ & $58 \%$ & .4 \\
\hline $\begin{array}{l}\text { DiGeorge } \\
\text { syndrome }\end{array}$ & $9(0)$ & $18 \%$ & $19(0)$ & $28 \%$ & .2 & $9(0)$ & $14 \%$ & $15(0)$ & $16 \%$ & .6 \\
\hline $\begin{array}{c}\text { Other cardiac } \\
\text { anomalies }\end{array}$ & $12(0)$ & $24 \%$ & $13(0)$ & $19 \%$ & .5 & $9(0)$ & $14 \%$ & $19(0)$ & $21 \%$ & .3 \\
\hline $\begin{array}{l}\text { Other medical } \\
\text { problems }\end{array}$ & $14(0)$ & $27 \%$ & $35(0)$ & $51 \%$ & .01 & $22(0)$ & $33 \%$ & $25(0)$ & $27 \%$ & .4 \\
\hline \multicolumn{11}{|l|}{$\begin{array}{l}\text { Patient data at time of } \\
\text { questionnaire } \\
\text { completion }\end{array}$} \\
\hline Age, y & $51(0)$ & $\begin{array}{c}15.6 \pm 1.5,15.8 \\
(12.9-17.8)\end{array}$ & $69(0)$ & $\begin{array}{l}15.7 \pm 1.39,15.9 \\
(13.2-18.0)\end{array}$ & .9 & $66(0)$ & $\begin{array}{c}19.9 \pm 1.3,19.6 \\
\quad(18.0-23.2)\end{array}$ & $92(0)$ & $\begin{array}{c}20.5 \pm 1.7,20.3 \\
\quad(18.0-23.6)\end{array}$ & .05 \\
\hline $\begin{array}{l}\text { Total medications } \\
\text { being taken }\end{array}$ & $51(0)$ & $1.0 \pm 1.3,0.0(0.0-5.0)$ & N/A & N/A & N/A & $65(1)$ & $0.9 \pm 1.4,0.0(0.0-9.0)$ & N/A & N/A & N/A \\
\hline $\begin{array}{l}\text { Median } \\
\text { neighborhood } \\
\text { family income } \\
\text { from last census } \\
\text { adjusted for } \\
\text { inflation (USD) }\end{array}$ & 49 (2) & $\begin{array}{l}64,306.2 \pm 26,676.0 \\
58,786.5(18,143.8- \\
128,666.8)\end{array}$ & N/A & N/A & N/A & $63(3)$ & $\begin{array}{l}70,319.2 \pm 27,540.0 \\
64,111.3(16,633.1- \\
140,766.4)\end{array}$ & N/A & N/A & N/A \\
\hline \multicolumn{11}{|l|}{$\begin{array}{l}\text { Patient morphologic } \\
\text { information }\end{array}$} \\
\hline Type A IAA & $19(0)$ & $37 \%$ & $19(0)$ & $28 \%$ & .3 & $23(0)$ & $35 \%$ & $32(0)$ & $35 \%$ & 1.0 \\
\hline Type B IAA & $31(0)$ & $61 \%$ & $50(0)$ & $72 \%$ & .2 & $43(0)$ & $65 \%$ & $60(0)$ & $65 \%$ & 1.0 \\
\hline Isolated VSD & $38(0)$ & $75 \%$ & $55(0)$ & $80 \%$ & .5 & $54(0)$ & $82 \%$ & $68(0)$ & $74 \%$ & .2 \\
\hline Large VSD size & $32(0)$ & $63 \%$ & $49(0)$ & $71 \%$ & .3 & $47(0)$ & $71 \%$ & $67(0)$ & $73 \%$ & .8 \\
\hline $\begin{array}{l}\text { Presence of an } \\
\text { anomalous right } \\
\text { subclavian }\end{array}$ & $12(0)$ & $24 \%$ & $12(0)$ & $17 \%$ & .4 & $14(0)$ & $21 \%$ & $24(0)$ & $26 \%$ & .5 \\
\hline $\begin{array}{l}\text { Presence of a } \\
\text { bicuspid aortic } \\
\text { valve }\end{array}$ & $13(0)$ & $25 \%$ & $14(0)$ & $20 \%$ & .5 & $26(0)$ & $39 \%$ & $37(0)$ & $40 \%$ & .9 \\
\hline
\end{tabular}




\begin{tabular}{|c|c|c|c|c|c|c|c|c|c|c|}
\hline \multirow[b]{2}{*}{ Variable } & \multicolumn{2}{|c|}{ CHQ-CF87, $n=51$} & \multicolumn{2}{|c|}{ CHQ-CF87 nonresponders, $n=69$} & \multirow[b]{2}{*}{$P$ value } & \multicolumn{2}{|c|}{ SF-36, $n=66$} & \multicolumn{2}{|c|}{ SF-36 nonresponders, $\mathrm{n}=\mathbf{9 2}$} & \multirow[b]{2}{*}{$P$ value } \\
\hline & $\begin{array}{l}\text { Number } \\
\text { (missing) }\end{array}$ & Value & $\begin{array}{l}\text { Number } \\
\text { (missing) }\end{array}$ & Value & & $\begin{array}{l}\text { Number } \\
\text { (missing) }\end{array}$ & Value & $\begin{array}{l}\text { Number } \\
\text { (missing) }\end{array}$ & Value & \\
\hline \multicolumn{11}{|l|}{$\begin{array}{l}\text { Characteristics of } \\
\text { index repair }\end{array}$} \\
\hline $\begin{array}{l}\text { Weight at index } \\
\text { IAA repair, kg }\end{array}$ & $40(11)$ & $\begin{array}{l}3.42 \pm 0.94,3.39 \\
\quad(2.20-8.00)\end{array}$ & $52(17)$ & $\begin{array}{l}3.14 \pm 0.44,3.20 \\
\quad(2.20-4.00)\end{array}$ & .09 & $59(7)$ & $\begin{array}{l}3.35 \pm 0.81,3.20 \\
(2.00-8.00)\end{array}$ & $79(13)$ & $\begin{array}{l}3.29 \pm 0.90,3.10 \\
(1.20-7.00)\end{array}$ & .3 \\
\hline Thoracotomy & $9(0)$ & $18 \%$ & $14(0)$ & $20 \%$ & .7 & $26(0)$ & $39 \%$ & $34(0)$ & $37 \%$ & .8 \\
\hline Direct arch repair & $30(0)$ & $59 \%$ & $49(0)$ & $71 \%$ & .2 & $39(0)$ & $59 \%$ & $53(0)$ & $58 \%$ & .9 \\
\hline $\begin{array}{l}\text { Arch repair using } \\
\text { patch }\end{array}$ & $19(0)$ & $37 \%$ & $17(0)$ & $25 \%$ & .1 & $12(0)$ & $18 \%$ & $25(0)$ & $27 \%$ & .2 \\
\hline $\begin{array}{l}\text { Gore-Tex } \\
\text { interposition } \\
\text { graft }\end{array}$ & $2(0)$ & $4 \%$ & $3(0)$ & $4 \%$ & 1.0 & $11(0)$ & $17 \%$ & $10(0)$ & $11 \%$ & .3 \\
\hline $\begin{array}{l}\text { Arch repair using } \\
\text { homograft } \\
\text { pulmonary artery }\end{array}$ & $7(0)$ & $16 \%$ & $7(0)$ & $10 \%$ & .4 & $5(0)$ & $8 \%$ & $10(0)$ & $11 \%$ & .5 \\
\hline $\begin{array}{l}\text { Cardiopulmonary } \\
\text { bypass used }\end{array}$ & $42(0)$ & $82 \%$ & $55(0)$ & $80 \%$ & .7 & $42(0)$ & $64 \%$ & $60(0)$ & $65 \%$ & .8 \\
\hline $\begin{array}{l}\text { Elapsed time on } \\
\text { bypass at index } \\
\text { repair, min* }\end{array}$ & $29(22)$ & $\begin{array}{l}81.31 \pm 73.05,70.00 \\
\quad(0.00-227.00)\end{array}$ & $46(23)$ & $\begin{array}{l}82.80 \pm 73.84,79.50 \\
\quad(0.00-326.00)\end{array}$ & .8 & $42(24)$ & $\begin{array}{l}44.69 \pm 59.91,0.00 \\
\quad(0.00-190.00)\end{array}$ & $55(37)$ & $\begin{array}{l}52.31 \pm 71.71,0.00 \\
(0.00-306.00)\end{array}$ & .8 \\
\hline $\begin{array}{l}\text { Total circulatory } \\
\text { arrest used }\end{array}$ & $41(0)$ & $80 \%$ & $55(3)$ & $83 \%$ & .7 & $42(0)$ & $64 \%$ & $60(0)$ & $65 \%$ & .8 \\
\hline $\begin{array}{l}\text { Total circulatory } \\
\text { arrest time at } \\
\text { index repair, min }\end{array}$ & $35(16)$ & $\begin{array}{c}36.40 \pm 27.84,46.00 \\
(0.00-104.00)\end{array}$ & $47(22)$ & $\begin{array}{l}41.51 \pm 28.49,46.00 \\
(0.00-105.00)\end{array}$ & .5 & $42(24)$ & $\begin{array}{l}24.57 \pm 31.23,0.00 \\
\quad(0.00-90.00)\end{array}$ & $63(29)$ & $\begin{array}{l}25.73 \pm 30.08,0.00 \\
\quad(0.00-109.00)\end{array}$ & .7 \\
\hline \multicolumn{11}{|l|}{$\begin{array}{l}\text { Procedural sequence } \\
\text { and timing }\end{array}$} \\
\hline $\begin{array}{l}\text { Total number of } \\
\text { surgical } \\
\text { procedures }\end{array}$ & $51(0)$ & $\begin{array}{l}1.98 \pm 1.05,2.00 \\
(1.00-5.00)\end{array}$ & $69(0)$ & $\begin{array}{l}1.51 \pm 0.72,1.00 \\
\quad(1.00-4.00)\end{array}$ & .01 & $66(0)$ & $\begin{array}{l}2.03 \pm 1.05,2.00 \\
\quad(1.00-4.00)\end{array}$ & $92(0)$ & $\begin{array}{l}1.79 \pm 0.97,2.00 \\
(1.00-6.00)\end{array}$ & .2 \\
\hline $\begin{array}{l}\text { Total number of } \\
\text { interventional } \\
\text { catheter-based } \\
\text { procedures }\end{array}$ & $51(0)$ & $\begin{array}{l}0.27 \pm 0.60,0.00 \\
\quad(0.00-3.00)\end{array}$ & $69(0)$ & $\begin{array}{l}0.42 \pm 0.79,0.00 \\
\quad(0.00-3.00)\end{array}$ & .4 & $66(0)$ & $\begin{array}{l}0.56 \pm 1.36,0.00 \\
\quad(0.00-8.00)\end{array}$ & $92(0)$ & $\begin{array}{l}0.40 \pm 0.85,0.00 \\
\quad(0.00-6.00)\end{array}$ & 1.0 \\
\hline $\begin{array}{l}\text { Total number of } \\
\text { other procedures }\end{array}$ & $51(0)$ & $\begin{array}{l}0.49 \pm 0.92,0.00 \\
\quad(0.00-5.00)\end{array}$ & $69(0)$ & $\begin{array}{l}0.41 \pm 0.93,0.00 \\
\quad(0.00-5.00)\end{array}$ & .4 & $66(0)$ & $\begin{array}{l}0.64 \pm 1.25,0.00 \\
\quad(0.00-9.00)\end{array}$ & $92(0)$ & $\begin{array}{l}0.58 \pm 1.19,0.00 \\
\quad(0.00-9.00)\end{array}$ & .5 \\
\hline
\end{tabular}




\begin{tabular}{|c|c|c|c|c|c|c|c|c|c|c|}
\hline \multirow[b]{2}{*}{ Variable } & \multicolumn{2}{|c|}{ CHQ-CF87, n = 51 } & \multicolumn{2}{|c|}{ CHQ-CF87 nonresponders, $\mathrm{n}=69$} & \multirow[b]{2}{*}{$P$ value } & \multicolumn{2}{|c|}{$\mathrm{SF}-36, \mathrm{n}=66$} & \multicolumn{2}{|c|}{ SF-36 nonresponders, $n=92$} & \multirow[b]{2}{*}{$P$ value } \\
\hline & $\begin{array}{l}\text { Number } \\
\text { (missing) }\end{array}$ & Value & $\begin{array}{l}\text { Number } \\
\text { (missing) }\end{array}$ & Value & & $\begin{array}{l}\text { Number } \\
\text { (missing) }\end{array}$ & Value & $\begin{array}{l}\text { Number } \\
\text { (missing) }\end{array}$ & Value & \\
\hline $\begin{array}{l}\text { Total number of } \\
\text { arch procedures }\end{array}$ & $51(0)$ & $\begin{array}{l}1.45 \pm 0.64,1.00 \\
(1.00-3.00)\end{array}$ & $69(0)$ & $\begin{array}{l}1.32 \pm 0.65,1.00 \\
(1.00-4.00)\end{array}$ & .1 & $66(0)$ & $\begin{array}{l}1.56 \pm 1.01,1.00 \\
(1.00-7.00)\end{array}$ & $92(0)$ & $\begin{array}{l}1.46 \pm 0.75,1.00 \\
(1.00-4.00)\end{array}$ & 7 \\
\hline $\begin{array}{l}\text { Total number of } \\
\text { LVOT } \\
\text { procedures }\end{array}$ & $51(0)$ & $\begin{array}{l}0.43 \pm 0.85,0.00 \\
\quad(0.00-3.00)\end{array}$ & $69(0)$ & $\begin{array}{l}0.28 \pm 0.59,0.00 \\
\quad(0.00-3.00)\end{array}$ & .5 & $66(0)$ & $\begin{array}{l}0.50 \pm 0.88,0.00 \\
(0.00-3.00)\end{array}$ & $92(0)$ & $\begin{array}{l}0.26 \pm 0.66,0.00 \\
(0.00-4.00)\end{array}$ & .06 \\
\hline $\begin{array}{l}\text { Time since last } \\
\text { procedure, y }\end{array}$ & $51(0)$ & $12.63 \pm 4.18$ & N/A & N/A & N/A & $64(2)$ & $15.49 \pm 5.15$ & N/A & N/A & N/A \\
\hline $\begin{array}{l}\text { Time since last } \\
\text { surgical } \\
\text { procedure, } y\end{array}$ & $51(0)$ & $12.93 \pm 4.10$ & N/A & N/A & N/A & $64(2)$ & $16.27 \pm 4.74$ & N/A & N/A & N/A \\
\hline $\begin{array}{l}\text { Reoperative } \\
\text { procedures }\end{array}$ & & & & & & & & & & \\
\hline $\begin{array}{l}\text { Reoperation with } \\
\text { total circulatory } \\
\text { arrest }\end{array}$ & $14(0)$ & $27 \%$ & $7(0)$ & $10 \%$ & .01 & $12(0)$ & $18 \%$ & $19(0)$ & $21 \%$ & .7 \\
\hline $\begin{array}{l}\text { Circulatory arrest at } \\
\text { any time }\end{array}$ & $16(10)$ & $39 \%$ & $57(0)$ & $83 \%$ & .8 & $49(0)$ & $74 \%$ & $73(0)$ & $79 \%$ & .5 \\
\hline $\begin{array}{l}\text { 22q11DS variables } \\
\text { Genetic or DNA } \\
\text { testing }\end{array}$ & $27(8)$ & $63 \%$ & N/A & N/A & N/A & $24(8)$ & $41 \%$ & N/A & N/A & N/A \\
\hline $\begin{array}{l}\text { Diagnosed with a } \\
\text { genetic condition }\end{array}$ & $19(8)$ & $44 \%$ & N/A & N/A & N/A & 17 (9) & $30 \%$ & N/A & N/A & N/A \\
\hline $\begin{array}{l}\text { Difficulties with } \\
\text { learning in } \\
\text { school }\end{array}$ & $34(2)$ & $69 \%$ & N/A & N/A & N/A & $38(3)$ & $60 \%$ & N/A & N/A & N/A \\
\hline $\begin{array}{l}\text { Behavioral } \\
\text { problems in } \\
\text { school }\end{array}$ & $9(3)$ & $19 \%$ & N/A & N/A & N/A & $10(4)$ & $16 \%$ & N/A & N/A & N/A \\
\hline $\begin{array}{l}\text { Mental health } \\
\text { counseling by a } \\
\text { social worker, } \\
\text { psychologist, or } \\
\text { psychiatrist }\end{array}$ & $19(2)$ & $39 \%$ & N/A & N/A & N/A & $16(5)$ & $26 \%$ & N/A & N/A & N/A \\
\hline $\begin{array}{l}\text { Medication for } \\
\text { mental health } \\
\text { problems }\end{array}$ & $13(1)$ & $26 \%$ & N/A & N/A & N/A & $8(5)$ & $13 \%$ & N/A & N/A & N/A \\
\hline
\end{tabular}




\begin{tabular}{|c|c|c|c|c|c|c|c|c|c|c|c|}
\hline \multirow[b]{2}{*}{ Variable } & \multicolumn{2}{|c|}{ CHQ-CF87, $\mathrm{n}=51$} & \multicolumn{3}{|c|}{ CHQ-CF87 nonresponders, $n=69$} & \multirow[b]{2}{*}{$P$ value } & \multicolumn{2}{|c|}{ SF-36, $n=66$} & \multicolumn{2}{|c|}{ SF-36 nonresponders, $n=92$} & \multirow[b]{2}{*}{$P$ value } \\
\hline & $\begin{array}{l}\text { Number } \\
\text { (missing) }\end{array}$ & Value & $\begin{array}{l}\text { Number } \\
\text { (missing) }\end{array}$ & & Value & & $\begin{array}{l}\text { Number } \\
\text { (missing) }\end{array}$ & Value & $\begin{array}{l}\text { Number } \\
\text { (missing) }\end{array}$ & Value & \\
\hline $\begin{array}{l}\text { Diagnosed with } \\
\text { anxiety }\end{array}$ & $6(5)$ & $13 \%$ & N/A & N/A & & N/A & $10(5)$ & $16 \%$ & N/A & N/A & N/A \\
\hline $\begin{array}{l}\text { Diagnosed with } \\
\text { depression }\end{array}$ & $1(3)$ & $2 \%$ & N/A & N/A & & N/A & $6(5)$ & $10 \%$ & N/A & N/A & N/A \\
\hline $\begin{array}{l}\text { Hearing tested and } \\
\text { told it wasn't } \\
\text { normal }\end{array}$ & $14(4)$ & $30 \%$ & N/A & N/A & & N/A & $10(4)$ & $16 \%$ & N/A & N/A & N/A \\
\hline Wear hearing aids & $4(2)$ & $8 \%$ & N/A & N/A & & N/A & $1(6)$ & $2 \%$ & N/A & N/A & N/A \\
\hline $\begin{array}{l}\text { Low calcium levels } \\
\text { ever }\end{array}$ & $10(17)$ & $29 \%$ & N/A & N/A & & N/A & $12(15)$ & $24 \%$ & N/A & N/A & N/A \\
\hline $\begin{array}{l}\text { Ever calcium } \\
\text { supplements or } \\
\text { medications to } \\
\text { correct calcium } \\
\text { levels }\end{array}$ & $10(6)$ & $22 \%$ & N/A & N/A & & N/A & $9(8)$ & $16 \%$ & N/A & N/A & N/A \\
\hline $\begin{array}{l}\text { Ever thyroid } \\
\text { problems }\end{array}$ & $3(9)$ & $7 \%$ & N/A & N/A & & N/A & $4(10)$ & $7 \%$ & N/A & N/A & N/A \\
\hline Ever speech therapy & $36(1)$ & $72 \%$ & N/A & N/A & & N/A & $30(5)$ & $49 \%$ & N/A & N/A & N/A \\
\hline $\begin{array}{l}\text { Recurrent } \\
\text { childhood } \\
\text { infections } \\
\text { requiring } \\
\text { medication or } \\
\text { admission to } \\
\text { hospital }\end{array}$ & $14(2)$ & $29 \%$ & N/A & N/A & & N/A & $12(6)$ & $6 \%$ & N/A & N/A & N/A \\
\hline $\begin{array}{l}\text { Ever told by a } \\
\text { doctor you have } \\
\text { any abnormal } \\
\text { facial features }\end{array}$ & $13(4)$ & $28 \%$ & N/A & N/A & & N/A & $11(10)$ & $20 \%$ & N/A & N/A & N/A \\
\hline $\begin{array}{l}\text { Ever diagnosed } \\
\text { with DiGeorge } \\
\text { syndrome }\end{array}$ & $16(10)$ & $39 \%$ & N/A & N/A & & N/A & $14(10)$ & $25 \%$ & N/A & N/A & N/A \\
\hline
\end{tabular}

Data are presented as numbers (\%) or mean \pm standard deviation. Note only variables with $>5$ events and $<40 \%$ missing data were included in multivariable analysis. CHQ-CF87, Child Health Questionnaire-Child Form $87 ;$ SF-36, Medical Outcomes Study Short Form-36 Health Survey version 2; N/A, not available; USD, United States dollars; IAA, interrupted aortic arch; VSD, ventricular septal defect; LVOT, left ventricular outflow tract; 22q11DS, 22q11 deletion syndrome. *The variable "elapsed time on bypass" (minutes) and the corresponding transformations were included in multivariable analysis although it had $43 \%$ of data missing for the CHQ-CF87 (SF-36, missing $=36 \%$ ) (see explanation in "Methods - Statistical Analysis"). 


\section{APPENDIX E3. 22Q11 DELETION SYNDROME (22q11DS) DEVELOPMENT, VALIDATION, QUESTIONNAIRE, AND RAW RESPONSES, $\mathrm{N}=141$}

\section{Development and Validation}

This questionnaire was developed by first determining the features of 22q11DS as reported in the literature, then the development of the questions with a focus on content and wording, organizing the questions in a meaningful order and format, testing, and validation within the Congenital Heart Surgeons' Society (CHSS) Data Center using cognitive debriefing during development to ensure the questions were appropriately comprehended, and finally revision. The questionnaire assessed patients in the following domains for potential self-reported features of 22q11DS: genetic conditions, learning, behavior, mental health, hearing, health issues related to calcium or thyroid problems, and other medical problems (speech related, infections, and abnormal facial features).

\section{Questionnaire and Raw Responses Genetic Conditions}

1. Have you ever had any genetic or DNA testing? Please check one only.

\begin{tabular}{ll}
\hline Yes & $72=52 \%$ \\
No & $52=38 \%$ \\
Do not know & $14=10 \%$ \\
Missing & $3=2 \%$ \\
\hline
\end{tabular}

2. If you have had genetic or DNA testing, why did you have this genetic testing done? Please check one only.

\begin{tabular}{lc}
\hline I have not had genetic or DNA testing & $36 / 52=85 \%$ \\
Possible problem & $48 / 70=69 \%$ \\
$2 / 70=3 \%$ \\
Routine Testing & $5 / 70=7 \%$ \\
Do not know & $15 / 70=21 \%$ \\
\hline Other & $2 / 72=7 \%$ \\
Missing & 15 \\
If other (please specify) & 2 \\
To confirm genetic defect & 3 \\
?DiGeorge & 1 \\
?22q11 & 1 \\
?Velocardiofacial syndrome & 1 \\
Voluntary & 7 \\
\hline Other & \\
\hline
\end{tabular}

3. Have you ever been diagnosed with any genetic conditions? Please check one only.

\begin{tabular}{ll}
\hline Yes & $48=36 \%$ \\
No & $77=57 \%$ \\
Do not know & $10=7 \%$ \\
Missing & $6=4 \%$ \\
\hline
\end{tabular}

4. If the answer to question 3 is yes, with what condition have you been diagnosed?

\begin{tabular}{ll}
\hline 22q11 & $8 / 43=19 \%$ \\
\hline DiGeorge & $22 / 43=51 \%$ \\
\hline Velocardiofacial syndrome & $7 / 43=16 \%$ \\
\hline DiGeorge/velocardiofacial syndrome & $1 / 43=2 \%$ \\
\hline Heart-related condition & $2 / 43=5 \%$ \\
Truncus arteriosus & $1 / 43=2 \%$ \\
Other & $2 / 43=5 \%$ \\
Missing & $5 / 48=10 \%$ \\
\hline
\end{tabular}

\section{Learning, Behavior, and Mental Health}

5. Have you ever had difficulties with learning in school (eg, did you need special assistance)? Please check one only.

\begin{tabular}{ll}
\hline Yes & $99=71 \%$ \\
No & $40=29 \%$ \\
Do not know & $0=0 \%$ \\
Missing & $2=1 \%$ \\
\hline
\end{tabular}

6. If the answer to question 5 is yes, what type of learning problems have you had?

\begin{tabular}{ll}
\hline Special education & $16 / 75=21 \%$ \\
$\begin{array}{l}\text { Subject/language/speech difficulties/cognitive/ } \\
\text { comprehension/development/processing/ } \\
\text { learning }\end{array}$ & $45 / 75=60 \%$ \\
$\begin{array}{l}\text { Concentration/attention deficit disorder (ADD)/ } \\
\text { attention deficit hyperactivity disorder }\end{array}$ & $9 / 75=12 \%$ \\
$\quad$ (ADHD) & \\
$\begin{array}{l}\text { ADHD with either special education or Learning } \\
\text { issue }\end{array}$ & $2 / 75=3 \%$ \\
\hline $\begin{array}{l}\text { Other } \\
\text { Missing }\end{array}$ & $3 / 75=4 \%$ \\
\hline
\end{tabular}

7. Have you ever had any behavioral problems in school (eg, suspension)? Please check one only.

\begin{tabular}{ll}
\hline Yes & $27=19 \%$ \\
No & $111=80 \%$ \\
Do not know & $1=1 \%$ \\
Missing & $2=1 \%$ \\
\hline
\end{tabular}


8. If the answer to question 7 is yes, what behavioral problems have you had?

\begin{tabular}{ll}
\hline Detention/suspension & $4 / 21=19 \%$ \\
$\begin{array}{l}\text { Anger/frustration/talking } \\
\text { back or in class Losing } \\
\text { control/hitting/ } \\
\text { inappropriate behavior }\end{array}$ & $7 / 21=33 \%$ \\
\hline $\begin{array}{l}\text { Social skills } \\
\text { Trouble focusing }\end{array}$ & $2 / 21=10 \%$ \\
\hline $\begin{array}{l}\text { Autism/not sitting in seat/not } \\
\text { obeying/obsessive- } \\
\text { compulsive disorder (OCD) }\end{array}$ & $1 / 21=5 \%$ \\
\hline $\begin{array}{l}\text { Apathy } \\
\text { Self-injury/hitting/ } \\
\text { threatening/cursing }\end{array}$ & $1 / 21=5 \%$ \\
\hline DiGeorge/anxiety & $1 / 21=5 \%$ \\
\hline Panic attacks/autism & $1 / 21=5 \%$ \\
\hline ADHD/Graves' disease & $1 / 21=5 \%$ \\
\hline Nothing serious & $1 / 21=5 \%$ \\
\hline Missing & $1 / 21=5 \%$ \\
\hline
\end{tabular}

9. Have you ever had any mental health counseling by a social worker, psychologist, or psychiatrist? Please check one only.

\begin{tabular}{ll}
\hline Yes & $50=36 \%$ \\
No & $88=63 \%$ \\
Do not know & $2=1 \%$ \\
Missing & $1=1 \%$ \\
\hline
\end{tabular}

10. If the answer to question 9 is yes, why did you have counseling?

\begin{tabular}{ll}
\hline Mood/fear/anxiety/depression/suicidal & $8 / 33=24 \%$ \\
\hline Psychiatric & $1 / 33=3 \%$ \\
\hline Family/divorce/abuse & $4 / 33=12 \%$ \\
\hline Behavior/anger & $4 / 33=12 \%$ \\
\hline Social skills & $1 / 33=3 \%$ \\
\hline ADHD & $1 / 33=3 \%$ \\
\hline Autism & $2 / 33=6 \%$ \\
\hline Combination of social/ADD/ADHD & $1 / 33=3 \%$ \\
\hline Combination ADD/depression/social & $1 / 33=3 \%$ \\
\hline Combination behavior/agitation/aggression/ & $1 / 33=3 \%$ \\
\hline OCD & \\
\hline Patient's request & $1 / 33=3 \%$ \\
\hline Parent's request & $1 / 33=3 \%$ \\
\hline Psychiatric related & $2 / 33=6 \%$ \\
\hline Unable to determine patient's given answer & $1 / 33=3 \%$ \\
\hline Other & $5 / 33=15 \%$ \\
\hline Don't know & $1 / 33=3 \%$ \\
\hline Missing & $17 / 50=34 \%$ \\
\hline
\end{tabular}

11. Have you ever taken medication for mental health problems? Please check one only.

\begin{tabular}{ll}
\hline Yes & $29=21 \%$ \\
No & $110=79 \%$ \\
Do not know & $0=0 \%$ \\
Missing & $2=1 \%$ \\
\hline
\end{tabular}

12. Have you ever been diagnosed with anxiety? Please check one only.

\begin{tabular}{ll}
\hline Yes & $20=14 \%$ \\
No & $115=82 \%$ \\
Do not know & $5=4 \%$ \\
Missing & $1=1 \%$ \\
\hline
\end{tabular}

13. Have you ever been diagnosed with depression? Please check one only.

\begin{tabular}{ll}
\hline Yes & $8=6 \%$ \\
No & $128=92 \%$ \\
Do not know & $3=2 \%$ \\
Missing & $2=1 \%$ \\
\hline
\end{tabular}

14. Have you ever been diagnosed with schizophrenia? Please check one only.

\begin{tabular}{ll}
\hline Yes & $2=1 \%$ \\
No & $134=96 \%$ \\
Do not know & $3=2 \%$ \\
Missing & $2=1 \%$ \\
\hline
\end{tabular}

\section{Other Medical Problems}

\section{Hearing}

15. Have you ever had your hearing tested and been told it wasn't normal? Please check one only.

\begin{tabular}{ll}
\hline Yes & $31=22 \%$ \\
No & $104=75 \%$ \\
Do not know & $4=3 \%$ \\
Missing & $2=1 \%$ \\
\hline
\end{tabular}

16. If the answer to question 15 is yes, why was your hearing abnormal?

\begin{tabular}{ll}
\hline Anatomical defect & $5 / 17=29 \%$ \\
Hearing loss/deafness & $7 / 17=41 \%$ \\
Fluid in ears & $2 / 17=12 \%$ \\
Fluid in ears/auditory & $1 / 17=6 \%$ \\
processing disorder & \\
Chronic ear infections & $1 / 17=6 \%$ \\
Don't know & $1 / 17=6 \%$ \\
\hline Missing & $14 / 31=45 \%$ \\
\hline
\end{tabular}


17. Do you wear hearing aids? Please check one only.

\begin{tabular}{ll}
\hline Yes & $6=4 \%$ \\
No & $129=96 \%$ \\
Missing & $6=4 \%$ \\
\hline
\end{tabular}

\section{Calcium}

18. Have you ever had low calcium levels? Please check one only.

\begin{tabular}{ll}
\hline Yes & $27=20 \%$ \\
No & $85=61 \%$ \\
Do not know & $27=19 \%$ \\
Missing & $2=1 \%$ \\
\hline
\end{tabular}

19. If the answer to question 18 is yes, why did you have low calcium levels?

\begin{tabular}{ll}
\hline As infant/child & $4 / 14=29 \%$ \\
\hline DiGeorge/?DiGeorge & $3 / 14=21 \%$ \\
\hline Hypoparathyroidism & $4 / 14=29 \%$ \\
?Genetic & $1 / 14=7 \%$ \\
\hline After heart surgery & $1 / 14=7 \%$ \\
During pregnancy & $1 / 14=7 \%$ \\
\hline Missing & $13 / 27=48 \%$ \\
\hline
\end{tabular}

20. Has a doctor ever given you calcium supplements or medication to correct your calcium levels? Please check one only.

\begin{tabular}{ll}
\hline Yes & $27=20 \%$ \\
No & $104=76 \%$ \\
Do not know & $6=4 \%$ \\
Missing & $4=3 \%$ \\
\hline
\end{tabular}

\section{Thyroid}

21. Have you ever had any problems with your thyroid? Please check one only.

\begin{tabular}{ll}
\hline Yes & $12=9 \%$ \\
No & $112=82 \%$ \\
Do not know & $13=9 \%$ \\
Missing & $4=3 \%$ \\
\hline
\end{tabular}

22. If the answer to question 21 is yes, what problem did you have?

\begin{tabular}{ll}
\hline Hypothyroidism & $4 / 7=57 \%$ \\
Thyroid removal & $1 / 7=14 \%$ \\
\hline At birth & $1 / 7=14 \%$ \\
Underdeveloped at birth & $1 / 7=14 \%$ \\
\hline Missing & $5 / 12=42 \%$ \\
\hline
\end{tabular}

\section{Other}

23. Have you ever had any speech therapy at any time in your life? Please check one only.

\begin{tabular}{ll}
\hline Yes & $87=63 \%$ \\
No & $51=37 \%$ \\
Do not know & $1=1 \%$ \\
Missing & $2=1 \%$ \\
\hline
\end{tabular}

24. If the answer to question 23 is yes, why did you have speech therapy?

\begin{tabular}{ll}
\hline Articulation/pronunciation & $19 / 51=37 \%$ \\
Delayed speech & $6 / 51=12 \%$ \\
\hline Cognitive issues & $6 / 51=12 \%$ \\
\hline Anatomical issues & $6 / 51=12 \%$ \\
\hline Cleft palate & $5 / 51=10 \%$ \\
\hline Any combination of above & $6 / 51=12 \%$ \\
\hline Feeding issues & $1 / 51=2 \%$ \\
\hline DiGeorge syndrome & $1 / 51=2 \%$ \\
\hline Unclear from patient answer & $1 / 51=2 \%$ \\
\hline Missing & $36 / 87=41 \%$ \\
\hline
\end{tabular}

25. Did you have recurrent childhood infections requiring medication or admission to hospital? Please check one only.

\begin{tabular}{ll}
\hline Yes & $30=22 \%$ \\
No & $106=77 \%$ \\
Do not know & $1=1 \%$ \\
Missing & $4=3 \%$ \\
\hline
\end{tabular}

26. Have you ever been told by a doctor that you have any abnormal facial features? Please check one only.

\begin{tabular}{ll}
\hline Yes & $32=23 \%$ \\
No & $99=72 \%$ \\
Do not know & $6=4 \%$ \\
Missing & $4=3 \%$ \\
\hline
\end{tabular}

\section{Summary of Findings}

Of the $141(51 \%)$ patients who completed the 22q11DS questionnaire, 52\% (72/141) reported having undergone genetic testing. Of those who had genetic testing, 48 of 70 $(69 \%)$ had testing to assess for a possible problem, as opposed to routine testing. The percentage of patients who answered the questionnaire who reported having been diagnosed with a genetic condition was 
$36 \%$ (48/135). Of these, 5 patients did not report their diagnosis. Of the remaining, 8 of $43(19 \%)$ reported a diagnosis of 22q11DS, 22 of $43(51 \%)$ reported DiGeorge, and 7 of $43(16 \%)$ reported velocardiofacial syndrome. The complete set of responses are listed in Appendix E3, question 4 . This is in contrast to $20 \%$ of patients (28/141) who were noted as having DiGeorge, as recorded in the medical records that were reviewed. Of note, many patients may not have been genetically tested secondary to the lack of testing available in the late 1980s and early 1990s, or may not have been clinically suspected of having the syndrome due to the wide spectrum of disease phenotypes (some cases being very mild). Therefore, in the remainder of the questionnaire we attempted to determine the prevalence of associated features, regardless of a 22q11DS diagnosis, based on selfreport using the 22q11DS questionnaire we had developed.

In the second section of the questionnaire, we asked patients about their learning, behavior, and mental health, as patients with 22q11DS often have deficiencies in these areas. We found that $71 \%(99 / 140)$ of patients who responded to the questionnaire reported difficulties with learning in school. Of the 99 who reported difficulties in school, 75 further described their learning problem, with $12 \%(9 / 75)$ reporting issues related to concentration/attention deficit disorder/attention deficit hyperactivity disorder, and $21 \%(16 / 75)$ receiving special education. We also found that $19 \%(27 / 139)$ self-reported behavioral problems, and the reasons varied widely. Finally, 36\% (50/ 140) of respondents reported having had mental health counseling for a wide variety of reasons, including mood/ fear/anxiety/depression/suicide $(24 \%=8 / 33)$, familyrelated issues $(12 \%=4 / 33)$, and behavior/anger issues $(12 \%=4 / 33)$. In addition, $21 \%(29 / 140)$ of patients reported having taken medications for mental health issues, $14 \%(20 / 140)$ had been diagnosed with anxiety, 6\% (8/ $139)$ with depression, and $1 \%(2 / 139)$ had been diagnosed with schizophrenia (which has a known association with 22q11DS).

In the third section of the questionnaire, we assessed other 22q11DS-associated medical problems. The percentage of patients who reported having had their hearing tested and having abnormal results was $22 \%(31 / 139)$, and $4 \%$ of patients (6/135) reported the need to use hearing aids. Another commonly associated feature is hypocalcemia, and $20 \%(27 / 139)$ of patients self-reported this, with the same number reporting having taken calcium supplements or medications to correct their calcium levels. The last 2 questions of this section related to thyroid problems, which were self-reported by $9 \%(12 / 137)$.

In the last section of the questionnaire, we assessed speech therapy, recurrent childhood infections and abnormal facies. Undergoing speech therapy was selfreported by $63 \%$ (87/139) of patients, with $37 \%$ (19/51) of these patients undergoing speech therapy for articulation and pronunciation. In addition, 22\% (30/137) reported recurrent infections requiring medication or admission to hospital. Surprisingly, 23\% (32/137) of patients reported having been told they had abnormal facial features by a doctor.

The changing denominator in the above results is due to missing responses.

\section{APPENDIX E4. DETAILED DESCRIPTION OF ADDITIONAL DATA COLLECTION, CONSENT, AND STATISTICAL METHODS \\ Data Collection}

Additional patient data were abstracted from copies of medical records submitted to the CHSS Data Center annually. These included records for initial and subsequent assessments, hospitalizations, and procedures. They were entered into a database by CHSS Data Center staff and member surgeons. These variables have been defined and described in our previous work. ${ }^{22}$

\section{Consent}

Institutional and patient participation was voluntary and confidential. Patients provided informed consent. Ethics approval for the CHSS Data Center is obtained annually from the Research Ethics Board of the Hospital for Sick Children, Toronto, Ontario, Canada. Institutional approval was obtained from the local site's institutional review board.

\section{Statistical Methods}

Data are expressed as the frequency, median with the range, or mean and standard deviation, with the number of missing values indicated. Response bias was sought by comparing categorical data for responders versus nonresponders using the $\chi^{2}$ or Fisher exact tests and continuous variables using the Wilcoxon 2-sample test. As both the Child Health Questionnaire-Child Form 87 (CHQ-CF87) and Medical Outcomes Study Short Form36 Health Survey version 2 (SF-36) are measured on different scales, with the CHQ-CF87 scored out of 100 and the SF-36 centered on a score of 50 , we derived $\mathrm{z}$ scores for our data using the published normative values to look at deviations from normal. This allowed for comparison between adolescents and young adults. For the CHQ-CF87, published scores obtained from 278 healthy children aged 10 to 15 years from a middle school in northeast United States were used as a normative reference. ${ }^{21}$ For the SF-36, normative comparison data was taken from the User's Manual for the SF-36v2 Health Survey and matched for age. ${ }^{20}$ Functional health status (FHS) scores of patients with interrupted aortic arch were compared with normative data using single-sample $t$ tests against a hypothesized mean. Multivariable linear regression was performed to assess associations with 
scores on each of the CHQ-CF87 and SF-36 scales with the variables listed in Appendix E2, along with data taken from the 22q11DS questionnaire. To identify the demographic, socioeconomic, lifestyle, morphologic, and procedure-related factors associated with the domains of the FHS questionnaires (ie, Physical Functioning, General Health, etc), a bootstrap bagging algorithm (1000 samples) was used that included all potential variables associated with the outcomes, with the exception of variables with an unacceptable amount of missing data $(>40 \%$ missing) or $<5$ events (Appendix E2). Missing data were imputed using the technique of mean imputation. The variable "elapsed time on bypass" (minutes) and the corresponding transformations were included in multivariable analysis although it had $43 \%$ of data missing for the CHQ-CF87 (SF36, missing $=36 \%$ ). We elected to include this variable, as it had a borderline amount of missing data only for one questionnaire. Clusters were also created that either solely included mathematical transformation of continuous variables, or in 4 cases had groups of related variables. These groups pertained to "patient reporting DNA testing" of any type, grouping use of "calcium supplements" and "medications to correct calcium levels," presence of any "other medical problems," and "having a diagnosis of a genetic condition" of any kind. Factors selected in at least $50 \%$ of the bootstrap samples were selected for further modeling. The final multivariable model for each FHS score was obtained through stepwise multivariable regression modeling, with backward selection of the variables selected using bootstrapping. Of note, final models in which any variables selected had missing data were further assessed to determine whether the missing data was important by using missing variable markers. Correlations were also assessed, and none were found to be present related to variables in the final models. Reliability indicates the percentage of bootstrap samples in which a given factor was selected. All regression models used a maximum likelihood algorithm to determine parameter estimates. All analyses were performed using Statistical Analysis Systems software, version 9.2 (SAS Institute, Inc, Cary, NC). 